NBER WORKING PAPER SERIES

\title{
DOES FINANCING SPUR SMALL BUSINESS PRODUCTIVITY? EVIDENCE FROM
} A NATURAL EXPERIMENT

\author{
Karthik Krishnan \\ Debarshi Nandy \\ Manju Puri \\ Working Paper 20149 \\ http://www.nber.org/papers/w20149
}

\author{
NATIONAL BUREAU OF ECONOMIC RESEARCH \\ 1050 Massachusetts Avenue \\ Cambridge, MA 02138 \\ May 2014
}

We would like to thank seminar participants at the 2013 Boston Area Finance Symposium, the 2013 CAFRAL Conference on Contemporary Issues in Banking and Finance, the 2013 FIRS annual meetings, the 2013 NBER Productivity, Innovation, and Entrepreneurship meetings, the 2013 SFS Cavalcade, Brandeis University, Duke University, Northeastern University, and Virginia Tech. Karthik Krishnan gratefully acknowledges summer research support provided by the D'Amore-McKim School of Business. The research presented in this paper was conducted while the authors were Special Sworn Status Researchers at the Boston Research Data Center (RDC) of the U.S. Census Bureau. The research results and conclusions expressed are those of the authors and do not necessarily indicate concurrence of the U.S. Census Bureau or the National Bureau of Economic Research. All results in this paper have been reviewed to ensure that no confidential information is disclosed. Any errors and omissions are the responsibility of the authors.

NBER working papers are circulated for discussion and comment purposes. They have not been peerreviewed or been subject to the review by the NBER Board of Directors that accompanies official NBER publications.

(C) 2014 by Karthik Krishnan, Debarshi Nandy, and Manju Puri. All rights reserved. Short sections of text, not to exceed two paragraphs, may be quoted without explicit permission provided that full credit, including $\left({ }^{\circ}\right.$ notice, is given to the source. 
Does Financing Spur Small Business Productivity? Evidence from a Natural Experiment Karthik Krishnan, Debarshi Nandy, and Manju Puri

NBER Working Paper No. 20149

May 2014

JEL No. G21

\begin{abstract}
$\underline{\text { ABSTRACT }}$
We analyze how increased access to financing affects firm total factor productivity (TFP) by exploiting a natural experiment following interstate banking deregulations which increased access to bank financing. We find that firms' TFP increases after their states implement these deregulations. Using a regression discontinuity approach based on Small Business Administration's funding eligibility criteria, we show that TFP increases following the deregulations are significantly greater for financially constrained firms. Our results suggest that greater access to financing allows financially constrained firms to invest in productive projects that may otherwise not be taken up.
\end{abstract}

Karthik Krishnan

Northeastern University

D'Amore-McKim School of Business Hayden 413, 360 Huntington Avenue Boston, MA 02115

k.krishnan@neu.edu

Debarshi Nandy

International Business School

Brandeis University

415 South Street

Waltham, MA, 02454

dnandy@brandeis.edu

\author{
Manju Puri \\ Fuqua School of Business \\ Duke University \\ 1 Towerview Drive, Box 90120 \\ Durham, NC 27708-0120 \\ and NBER \\ mpuri@duke.edu
}




\section{Does Financing Spur Small Business Productivity? Evidence from a Natural Experiment}

\section{Introduction}

Access to adequate financing is an important issue for firms, particularly for younger and smaller entrepreneurial firms. Given the important role that small businesses and entrepreneurial firms play in the process of creative destruction - it is not surprising that alleviating financial constraints for entrepreneurial start-ups and small business is an important policy concern across the world. More recently, the financial crisis of 2008 clearly demonstrated how critical access to bank financing is, at both the firm and economy-wide levels. While prior studies have shown how availability of financing affects entrepreneurial firm starts and closures (e.g., Black and Strahan (2002), Kerr and Nanda (2009)), no study has directly analyzed the link between increased access to bank financing and firm productivity, particularly for smaller firms where access to financing is critical. This is important given the result in a recent paper by Robb and Robinson (2013) that, counter to existing wisdom, most start-ups rely heavily on some form of bank-debt financing.

There are two important limitations that studies relating increased bank financing to firm productivity need to overcome. First, bank financing is considerably more important for private firms, and data on the performance of such firms is not easily accessible. Second, reverse causality and endogeneity issues hinder proper interpretation of regression coefficients relating increased access of bank financing to firm productivity. A positive relation between increased access to bank financing and productivity can be interpreted in different ways. One interpretation is that more productive firms seek additional bank financing. Another interpretation is that increased access to bank financing can enhance productivity of firms. Yet another alternative interpretation is that there are potentially unobservable factors which might affect both access to financing and productivity. Disentangling these effects requires a natural experiment setting where one can consider an exogenous shift in the availability of bank financing.

In this paper, we exploit such a natural experiment and contribute by analyzing how an increase in access to bank financing following interstate bank branching deregulations affects the productivity of firms in the United States. We overcome the data availability issue described above by using data 
on private and public manufacturing firms from the U.S. Census Bureau's Longitudinal Research Database (LRD). This database contains detailed data for small and large manufacturing firms in the U.S. over a long time-series from 1976 to 2005, which allows us to calculate productivity and performance measures at the firm level. We deal with the reverse causality concern by exploiting an exogenous shift in firms' access to bank financing as a result of interstate bank branching deregulations. In particular, over the 1990s, U.S. states began allowing out-of-state banks to set up and acquire local bank branches. This shift led to an overall increase in interstate banking and thus allowed greater access to financing for firms. Consistent with the prior literature (e.g., Rice and Strahan (2010)), which has shown that these deregulations were exogenous, we also show that these deregulations were not driven by the prior productivity of firms. In our main analyses, we utilize a regression discontinuity $(\mathrm{RD})$ framework that distinguishes between financially constrained and unconstrained firms. We argue that private firms that are just above or just below the threshold for financial support from the U.S. Small Business Administration (SBA) are similar in all respects except for the degree of financial constraint they face. Since firms that are just above the threshold are not eligible for SBA funding, they are more financially constrained relative to those just below the threshold. This allows us to analyze the causal impact of firm financial constraints on the relation between access to financing and productivity.

Rice and Strahan (2010) suggest that the interstate banking deregulations in the U.S. reduced the cost of financing. A natural question that follows is whether this increased access to cheaper bank financing following the deregulations is dissipated by firms taking on unproductive or less productive pet projects or whether this increases firms' ability to undertake additional productive projects that they were unable to take on prior to the deregulation. ${ }^{1}$ We use total factor productivity (TFP) of firms as our metric of analysis to address this question. Since our measure of total factor productivity reflects the difference between expected output, given the technology in place, and the actual output produced by the firm, gains in productivity as a result of increased access to financing is not simply a result of increase in the scale of operations, but rather the result of access to additional productive projects that allows a firm to become more efficient. Thus, increased access to financing should therefore lead to the highest increase in productivity for those firms that

\footnotetext{
${ }^{1}$ Note that throught this paper, increased access to financing refers to both access to greater volume of bank loans as well as bank financing at more favorable terms.
} 
were initially financially constrained.

We start by investigating whether firms in states that implement the Interstate Banking and Branching Efficiency Act of 1994 (IBBEA) and deregulate interstate banking within their borders to a greater extent achieve higher productivity. Similar to several other papers that have used the LRD database to study various corporate events (see, e.g., Schoar (2002), Maksimovich, Philips, and Prabhala (2011), Chemmanur, Krishnan, and Nandy (2011)), we use total factor productivity (TFP) as our measure of firm efficiency. TFP measures the residual growth in a firm's output after accounting for the growth in output attributable to the various factors of production and the production technology in place.

We first show that the number and out-of-state ownership of bank branches increased in states following the interstate bank branching deregulation, supporting our premise that in deregulating states, the IBBEA led to an increase in access to bank financing. Following Rice and Strahan (2010), we create a variable called Deregulation index, which increases with the extent of interstate branching deregulation in a state. We then show that productivity of firms increases in those states that allow greater interstate banking within their borders (i.e., have a greater value for Deregulation index). This result is robust to controlling for various state, firm, and industry level control variables. We show that the increase in TFP is not due to a trend effect, i.e., TFP is flat in the periods immediately prior to the interstate bank branching deregulations. Further, our main results disappear in placebo tests where we check whether TFP increases when we assume the deregulation to start one year prior to or one year after the actual deregulation year. As an additional robustness test, we also conduct our analysis using alternative measures of performance such as labor productivity and sales growth and find qualitatively similar results to the ones we find using the TFP measure.

We then investigate the mechanism through which increased access to financing leads to greater TFP. Using a sharp regression discontinuity (RD) approach, we test whether firms that are close to but do not satisfy the eligibility criteria for alternative funding sources; in particular, support from the Small Business Administration (SBA), experience a greater increase in the average 3-year TFP after the bank branching deregulations than firms that just satisfy the eligibility criteria. The U.S. Small Business Administration (SBA) provides a number of financial assistance programs 
for small businesses. ${ }^{2}$ We exploit the fact that the SBA provides financial support to firms up to a certain size cutoff as a way to distinguish firms that are more financially constrained from those that are less financially constrained. For manufacturing firms, the size cutoff is a prespecified level of employment that varies with the firm's North American Industry Classification System (NAICS) industry affiliation. We restrict our attention to the set of firms that have employment within 10 percent of this cutoff level (where employment is measured immediately prior to the interstate bank branching deregulation in the firm's state). The advantage of this restriction is that firms just above and just below the SBA threshold are unlikely to differ substantially in terms of other characteristics but differ in terms of their access to SBA financing. In particular, firms just above the SBA employment threshold are ineligible for SBA funding and are thus more financially constrained relative to firms just below the SBA employment threshold. It follows that, if productivity increases following bank branching deregulations are primarily driven by firms that are financially constrained, then TFP increases for firms just above the SBA threshold should be greater than TFP increases for firms just below the SBA threshold after the deregulation.

Our results for sharp $\mathrm{RD}$ analysis are consistent with this expectation. We find that firms ineligible for SBA support indeed experience a greater increase in the average TFP from before to after interstate bank branching deregulations compared to otherwise similar firms that are eligible for SBA support. This test therefore provides strong support for the argument that financially constrained firms benefit the most from increased access to financing. Further, since the control firms (SBA eligible firms) are similar to the set of treatment firms (SBA ineligible firms) that are financially constrained (since we look at a narrow $10 \%$ band around the employment eligibility criterion), this methodology provides additional assurance that our results are not driven by other, potentially unobservable, differences between firms. We also conduct this analysis with the set of firms whose employment is within $30 \%$ of the SBA employment threshold, within $50 \%$ of the SBA employment threshold, as well as our entire sample, and obtain similar results to those described here. Further, we also conduct our sharp RD analysis in a non-parametric framework (e.g., Imbens and Lemieux (2008) and Imbens and Kalyanaraman (2012)) and find similar results to those using the regression framework described above.

\footnotetext{
${ }^{2}$ In 2006, the total value of financial support provided by the SBA to small businesses was $\$ 78.1$ billion, which grew to $\$ 90.45$ billion in 2009 , indicating that the SBA represents a significant source of financial support for smaller firms.See http://www.sba.gov.
} 
Second, we employ a "quasi" regression discontinuity methodology, where we test, in a panel data setting, whether the relation between the extent of interstate bank branching deregulation (i.e., Deregulation index) and firm level TFP is affected by firm financial constraint (proxied by SBA eligibility). Unlike the sharp RD test described above, the quasi RD test is a differencesin-differences approach that interacts our Deregulation index with a dummy variable for firms being above the SBA threshold at the time of the deregulation in their state. The benefit of this methodology is that, unlike the sharp RD analysis, we can utilize the cross-state variation in the extent of interstate bank branching deregulation in the state of the firm. Moreover, we can conduct this test in a panel setting rather than in a cross-sectional setting of the sharp RD analysis. Our quasi-RD anlaysis results are consistent with those of the sharp RD analysis. In particular, firms just above the SBA eligibility threshold experience higher TFP increases in states with a greater extent of interstate banking deregulation, whereas firms just below the SBA eligibility threshold do not. For both the sharp and quasi RD analyses, we conduct a variety of robustness checks, including controlling for different powers of the assignment variable, and conducting placebo tests by falsifying the discontinuity point. Our results are robust to these tests.

We also use firm size measured immediately prior to the deregulation as another proxy for financial constraint. We use various size measures for this analysis, including sales (total value of shipments), assets (capital stock), and total employment. We find that the positive relation between the extent of bank branching deregulations in a state and firm TFP is stronger for smaller firms, consistent with the idea that firms that are more financially constrained benefit the most from increased access to financing. ${ }^{3}$ To dig deeper into whether financial constraints are indeed driving our results, we test whether our TFP results are stronger for firms in industries that are more financially constrained. We measure industry level financial constraint based on the measure suggested by Rajan and Zingales (1998). This measure is based on a free cash flow measure calculated using Compustat at the industry level. We find that industries classified as more dependent on external finance experience substantially greater increases in TFP for firms in states with greater extent of interstate bank branching deregulation than industries classified as less dependent on external finance.

\footnotetext{
${ }^{3}$ These results are consistent with those in Rice and Strahan (2010), who find that deregulation of interstate bank branching restrictions is associated with a higher probability that small firms borrow from banks.
} 
We are one of the first studies in the literature to address whether increased access to financing has a causal effect on firm-level TFP growth. ${ }^{4}$ There is a vast literature which has looked at whether finance creates productivity growth (e.g., Hicks (1969)) or follows growth (e.g., Robinson (1952)), but since finance and growth are endogenously determined, identifying the direction of causality has been a major hurdle in this literature. We address this by exploiting the interstate bank branching deregulations as a natural experiment. Existing literature that has utilized banking deregulations have analyzed entrepreneurship and startup activity (Black and Strahan (2002), Kerr and Nanda (2009)), growth within a country (Jayaratne and Strahan (1996), Guiso, Sapienza, and Zingales (2004)), access to credit (Cetorelli and Strahan (2006)), loan pricing (Rice and Strahan (2010)), and allocation of credit between poor and better performing firms (Bertrand, Schoar, and Thesmar (2007)). ${ }^{5}$ Our results add to these studies by causally establishing that greater access to financing leads to higher firm level TFP, particularly for financially constrained firms. The banking deregulations alleviated such constraints leading to an increase in their TFP.

A related strand of literature has documented how access to particular types of financing such as venture capital and angel financing can impact the survival and productivity of small and entrepreneurial firms (e.g., Puri and Zarutskie (2012), Chemmanur, Krishnan, and Nandy (2011), Kerr, Lerner, and Schoar (2013)). These papers show that for young startup firms, access to VC or angel financing can affect productivity and the lifecycle of these firms. However, only a small proportion of startups get VC or angel financing. Our paper shows that increased access to bank financing is important in affecting the productivity of smaller and financially constrained firms. This is crucial from a policy perspective if the objective is to promote the growth of startups especially given that most young firms rely heavily on bank financing (Robb and Robinson (2013)).

\footnotetext{
${ }^{4}$ A notable exception is Bertrand, Schoar, and Thesmar (2007) who show that improvements in performance of French firms followed after the government reduced state intervention in banking and reduced subsidized loans for poorly performing firms. However, our results are primarily driven by a positive shock to credit availability which led to increased competition in banking as a result of the interstate bank branching deregulation in the U.S., rather than due to the abolition of subsidized credit availability to poor quality borrowers as in Bertrand, Schoar, and Thesmar (2007).

${ }^{5}$ Also related to this broad literature, Butler and Cornaggia (2011) analyze how finance affects agricultural productivity. They find a large shift in corn productivity of farmers in response to the ethanol-induced shift in demand, and that this productivity improvement was most pronounced in counties with high levels of bank deposits.

${ }^{6}$ Fracassi, Germaise, Kogan, and Natividad (2013) analyze business microloans for U.S. subprime borrowers in a regression discontinuity framework. They find that the ability to obtain loans increases firms' survival probability, sales, and job creation rate. Unlike us, however, they do not analyze productivity and performance of firms following greater access to financing. Further, unlike us, they do not analyze how financial constraints affect the impact of access to finance on productivity.
} 
Another strand of literature uses international data to assess the role of finance in development and growth. Rajan and Zingales (1998) use cross-country data and find evidence consistent with the idea that financial development promotes economic growth for industries that are more dependent on external finance. Levine, Loayza, and Beck (2000) find that a greater extent of financial intermediation in a country has a positive effect on economic growth. Guiso, Sapienza, and Zingales (2004) use Italian data to show that better developed financial markets in a geographic region in Italy leads to greater startup activity by younger entrepreneurs and leads to greater economic growth in that region. We add to the findings of this literature by showing firm-level productivity improvements following increased access to financing in the U.S. Finally, this paper is related to the broader literature on financing constraints of firms (e.g., Fazzari, Hubbard, and Peterson (1988), Kaplan and Zingales (1997, 2000), Moyen (2004), Denis and Sibilkov (2010), and Denis and McKeon (2012)).

\section{Interstate Banking Regulations in the U.S.}

Various regulations in the US restricted intra as well as interstate banking dating back to the 19th century. The McFadden Act of 1927 restricted cross-state banking and state level regulations prevented banks from intra-state expansions. Although banks tried to get around these regulations by forming multi-bank holding companies (MBHCs), the Douglas Amendment to the 1956 Bank Holding Company (BHC) Act effectively prevented banks' expansion across state borders, unless states explicitly permitted such expansion. However, states gradually dismantled these restrictions and many states had laws in place allowing interstate banking by 1992, which primarily took the form of allowing out-of-state banks to buy in-state banks. However, interstate bank branching was still not allowed until the passage of the Interstate Banking and Branching Efficiency Act of 1994 $\left(\right.$ IBBEA). ${ }^{7}$

The passage of IBBEA effectively permitted bank holding companies to operate branches across state lines. However, states were given the ability to erect roadblocks to branch expansion, effectively allowing states to dissuade interstate branching based on the following four dimensions.

\footnotetext{
${ }^{7}$ See Kerr and Nanda (2009) and Rice and Strahan (2010) for detailed descriptions of banking regulations in the U.S. over this period.
} 
1. Age restriction: States could require that a bank seeking to enter its boundaries should have existed for a minimum number of years, subject to a maximum restriction of 5 years.

2. De novo interstate branching restriction: States could disallow de novo interstate bank branching.

3. Individual branch acquisition restriction: States could make interstate acquisition of banks more difficult by requiring that all branches of an in-state target bank be acquired by an out-of-state bidder bank.

4. Statewide cap on deposits restriction: States could restrict the fraction of deposits an out-ofstate bank could acquire in that state. The IBBEA originally set this restriction on deposit concentration at 30\%, but states have the discretion to increase or decrease the cap.

These provisions provided states with tools to effectively constrain interstate bank branching. Many states successfully utilized these provisions to bar out-of-state banks from setting up branches within their borders. The IBBEA was passed in 1994, but states had the discretion to set up their interstate bank branching regulations under the IBBEA anytime before 1997. As a result, these deregulations were implemented in a staggered manner, thereby allowing us to exploit them to analyze how an increase in access to financing as a result of these deregulations affect the productivity and performance of firms. Following Rice and Strahan (2010), our primary measure of deregulation is Deregulation Index, which is a measure of the extent of deregulation of interstate bank branching in a state. The index can take values between one to five, one being the least deregulated, i.e., where all four restrictions described above were placed to prevent interstate branching; and five is the least restricted, where none of the restrictions were placed. This index increases by one if the restriction decreases by one (of the four described above). In particular, we add one to this index if the state does not impose a minimum age requirement, if the state permits acquisition of individual bank branches, if the state permits denovo branching, and if the state imposes a deposit cap that is the same as or larger than the IBBEA default (i.e., 30\%). This index takes the value zero for all years before the state implements interstate bank branching deregulation. ${ }^{8}$

\footnotetext{
${ }^{8}$ We also conduct our TFP analyses using a dummy variable that is one in the years after the state of a firm deregulates interstate bank branching as the proxy for access to financing. Our results are qualitatively similar to those reported here.
} 
Certain states offered these four provisions with reciprocity (see, e.g., Johnson and Rice (2008)). This requirement allowed a particular action by an out-of-state bank so long as the laws of the home state of that out-of-state bank were reciprocal, permitting the same level of interstate banking. We thus also create a Deregulation $\&$ reciprocity index, which is Deregulation Index plus one for states that do not require reciprocity (thus increasing the pool of out-of-state banks that can expand within their territory). Table 1 reports the state level interstate bank branching laws and the dates on which they were implemented. The data for this table is obtained from Johnson and Rice (2008) and Rice and Strahan (2010).

\section{Data, Sample Selection, and Construction of Variables}

The primary data used in this study is obtained from the LRD, which maintained by the Center of Economic Studies at the U.S. Census Bureau. ${ }^{9}$ The LRD is a large micro database that provides plant-level information for firms in the manufacturing sector for each year. In the census years (1972, 1977, 1982, 1987, 1992, 1997, and 2002), the LRD covers the entire universe of manufacturing plants in the Census of Manufacturers (CM). In non-census years, the LRD tracks approximately 50,000 manufacturing plants every year in the Annual Survey of Manufacturers (ASM), which covers all plants with more than 250 employees with probability one. In addition, it also includes smaller plants that are randomly selected every fifth year to complete a rotating five-year panel. Therefore, all U.S. manufacturing plants with more than 250 employees are included in the LRD database on a yearly basis from 1972 to 2005, and smaller plants with fewer than 250 employees are included in the LRD database every census year and are also randomly included in the non-census years, continuously for five years, as a rotating five year panel. ${ }^{10}$ Most of the data items reported in the LRD (e.g., the number of employees, employee compensation, and total value of shipments) represent items that are also reported to the IRS, increasing the accuracy of the data.

To verify longitudinal links of firms in the Census data, we also use two alternate data sources maintained by the U.S. Census Bureau, namely the Standard Statistical Establishment List (SSEL),

\footnotetext{
${ }^{9}$ See McGuckin and Pascoe (1988), who provide a detailed description of the Longitudinal Research Database (LRD) and the method of data collection.

${ }^{10}$ Given that a random sample of smaller plants is continuously present in our sample, our data is not substantially skewed toward larger firms; smaller firms are well represented in the data. The rotating sample of smaller plants is sampled by the Census Bureau each year in the non-census years in order to minimize such a bias in the data.
} 
and the Longitudinal Business Database (LBD). ${ }^{11}$ The major advantage of using the LRD relative to the LBD for this study is the following: assets, sales, operating costs, investments, and other such firm-level information are mostly not covered in the LBD. Thus, our overall metric of firm efficiency-i.e., total factor productivity (TFP)-can only be constructed for the LRD panel.

We focus our analysis on private firms, since they are expected to respond more to increased access in bank financing, than publicly traded firms. To this end, we identify all public firms (as defined by CRSP) for every year in our sample and remove them from the LRD by using either the Compustat-SSEL bridge or a name and address matching methodology as outlined in previous studies (e.g., Chemmanur, Krishnan, and Nandy (2011)). Thus, in any given year within our sample, we are left with only private firms, representing 570,596 firm-years of data for 137,009 firms. ${ }^{12}$

\subsection{Measurement of Total Factor Productivity (TFP)}

The primary measure of firm efficiency used in our analysis is total factor productivity, which is calculated from the LRD for each individual establishment at the annual three-digit North American Industrial Classification System (NAICS) industry level. Firm-level TFP is then calculated as a weighted sum of plant TFP for each year. Increasingly, several articles in the finance and economics literature have used TFP to measure firm efficiency; see, e.g., Lichtenberg and Siegel (1990), McGuckin and Nguyen (1995), Maksimovic, Philips, and Prabhala (2011), and Chemmanur, He, and Nandy (2010), among others. We obtain measures of TFP at the establishment level, by estimating a log-linear Cobb-Douglas production function for each industry and year. Industry is defined at the level of three-digit NAICS codes. ${ }^{13}$ Individual plants are indexed $i$, industries $j$,

\footnotetext{
${ }^{11}$ The SSEL is the Business register of the US Census Bureau, which records the name, address, and some other details of every single establishment in the US. Similar to the LRD, the LBD is created from the SSEL and is also a panel data set that tracks the set of U.S. business establishments from 1975 to the present. While the LRD is limited to the manufacturing sector, the LBD encompasses all industry sectors.

${ }^{12}$ It should be noted that both the SSEL and the LRD provide establishment-level (i.e., plant-level) data. For the purpose of our analysis we aggregate this data to the firm level using standard techiniques used in the literature previously (for example, see Chemmanur, He, and Nandy (2010)) and numerical identifiers for plants and firms provided in the LBD and LRD, which we discuss further below.

${ }^{13}$ As a robustness check, we reestimate the production function in several different ways. First, we use two- and three-digit SIC industry classifications. Second, we estimate TFP with value-added production function specifications and separate white- and blue-collar labor inputs. Third, we divide each annual four-digit SIC industry into two groups based on capital intensity-i.e., establishments with capital intensity greater than the median capital intensity for that annual industry group are put in one category, while those with capital intensity less than the median are put in another category. We then estimate the production function for each category separately. In all cases we find qualitatively equivalent results.
} 
for each year $t$ in the sample:

$$
\ln \left(Y_{i j t}\right)=\alpha_{j t}+\beta_{j t} \ln \left(K_{i j t}\right)+\gamma_{j t} \ln \left(L_{i j t}\right)+\delta_{j t} \ln \left(M_{i j t}\right)+\varepsilon_{i j t} .
$$

We use the LRD data to construct the variables in the production function as closely as possible. Output (Y) is constructed as plant sales (total value of shipments in the LRD) plus changes in the value of inventories for finished goods and work-in-progress. ${ }^{14}$ Since we appropriately deflate plant sales by the annual industry-specific price deflator, our measure should be proportional to the actual quantity of output.

Labor input $(\mathrm{L})$ is defined as production-worker-equivalent man-hours-that is, the product of production-worker man-hours, and the ratio of total wages and salaries to production-worker wages. We also reestimate the TFP regression by specifying labor input to separately include non-production workers, which yields qualitatively similar results. Values for capital stock (K) are generated by the recursive perpetual inventory formula. We use the earliest available book value of capital as the initial value of net stock of plant capital (this is either the value in 1972, or the first year a plant appears in the LRD sample). These values are written forward annually with nominal capital expenditure (appropriately deflated at the industry level) and depreciated by the economic depreciation rate at the industry level obtained from the Bureau of Economic Analysis. Since values of all these variables are available separately for buildings and machinery, we perform this procedure separately for each category of assets. The resulting series are then added together to yield our capital stock measure.

Finally, material input (M) is defined as expenses for the cost of materials and parts purchased, resales, contract work, and fuel and energy purchased, adjusted for the change in the value of material inventories. All the variables are deflated using annual price deflators for output, materials, and investment at the three-digit NAICS level from the Bartelsman and Gray National Bureau of Economic Research (NBER) Productivity Database. ${ }^{15}$ Deflators for capital stock are available from the Bureau of Economic Analysis. ${ }^{16}$ Plant-level TFP is then computed as the residuals of regression (1), estimated separately for each year and each three-digit NAICs industry. Therefore,

\footnotetext{
${ }^{14}$ More accurately, we use log of one plus revenue and cost measures so as not to exclude firms that have zero values for these variables.

${ }^{15}$ See Bartelsman and Gray (1996) for details.

${ }^{16}$ See Lichtenberg (1992) for a detailed description of the construction of TFP measures from LRD variables.
} 
the average TFP (i.e., the average of the residuals) in any three-digit NAICs industry-year is zero by construction. Plant-level TFP measures are then aggregated to the firm level by a value-weighted approach, where the weight on a plant is the ratio of its output (total value of shipments) to the total output of the firm. ${ }^{17}$ The firm-level TFP is then winsorized at the first and 99 th percentiles. ${ }^{18}$

\subsection{Other Variables Used in the Analysis}

In this subsection we discuss the construction and measurement of the different firm-specific variables as well as other proxies used in our analysis. The LRD contains detailed information at the plant level on the various production function parameters, such as total value of shipment, employment, labor costs, material costs, new capital investment for the purchase of buildings, machinery, equipment, etc. Using this detailed information, we first construct the variables of interest at the plant-level, and then aggregate the plant level information to firm-level measures.

Capital Stock is constructed via the perpetual inventory method, discussed in Section 3.1. Capital Expenditure is the dollar value the firm spends on the purchase and maintenance of plant, machinery, and equipment, etc. Material Cost is the expense for the cost of materials and parts purchased, resales, contract work, and fuel and energy purchased. Salaries and Wages is the total production-worker wages plus total non-production-worker wages plus total supplemental labor costs, which include both legally required supplemental labor costs as well as voluntary supplemental labor costs of the firms. Total Production Cost is calculated as the sum of materials cost plus rental and administrative expenditures. All values in the LRD are in thousands of dollars (in 1998 real terms), and all plant-level measures are winsorized at the 1st and 99th percentile.

We define Assets as the natural logarithm of capital stock of the firm. We construct the industry Herfindahl Index based on the market share measure of each firm in the LRD. Market share is defined as the firm's market share in terms of sales at the annual three-digit NAICS level. The Herfindahl Index is calculated by summing up the square of each firm's market share (in sales) at the annual three-digit NAICS level. A higher Herfindahl Index means that the industry is more

\footnotetext{
${ }^{17}$ As a robustness check, we also used the ratio of its capital stock to the total capital stock of the firm and the ratio of plant employment to firm employment as weights. In all cases, our results remain qualitatively unchanged.

${ }^{18}$ Another concern is whether technology shocks can affect TFP and inputs simultaneously which in turn may bias our results (see, e.g., Olley and Pakes (1996) and Levinsohn and Petrin (2003)). We address this concern by recalculating TFP based on the methodology proposed by Levinsohn and Petrin (2003) and find qualitatively similar results.
} 
concentrated. Firm age is calculated as the time from the birth to current year of the oldest plant of a firm. We use the LBD to calculate the firm age, since it is derived from the U.S. Business Register files that has data on the universe of U.S. establishments for all years.

We also define External Financial Dependence of a firm's industry based on the measure of external financial dependence proposed by Rajan and Zingales (1998) and used in Cetorelli and Strahan (2006). To construct this measure, we take all firms on Compustat between 1978 and 2005. We exclude "young" Compustat firms, that is, firms that had gone public only recently. A measure of external financial dependence for such firms is likely to be nonrepresentative of the typical needs of a firm in a given sector. We define firms as young if they appear in Compustat for 10 years or less. We then sum across all years each firm's total capital expenditures (Pre-Xpressfeed Compustat item \# 128) minus cash flow from operations. Cash flow from operations equals revenues minus nondepreciation costs (Pre-Xpressfeed Compustat item \# 110) plus decreases in inventories and accounts receivable plus increases in accounts payable. ${ }^{19}$ This sum equals the total external funds needed to finance investments. A negative value for this sum means that the firm had free cash flow available for disbursement to shareholders or to pay down debt. A positive value for this sum means that the firm needed to raise additional capital to finance its investment. We then divide this free cash flow figure by total capital expenditure. After constructing this ratio for each firm, we use the median value for all firms in each three-digit NAICS category and define a dummy called External Financial Dependence as one if this value is positive for the industry and zero otherwise.

In addition to the firm-specific and industry-wide controls mentioned above, we also use separate variables for our "sharp" regression discontinuity and "quasi" regression discontinuity analyses. The U.S. SBA provides a number of financial assistance programs for small businesses. To analyze the effect of the deregulation on financially constrained firms, we exploit the fact that the SBA provides financial support to firms up to a certain size cutoff. For manufacturing firms, this size cutoff is a prespecified level of employment that varies with the North American Industry Classification System (NAICS) industry affiliation of the firm. ${ }^{20}$ For a firm, the variable $S B A$ Eligible is one if, in the closest year prior to the year of the interstate bank branching deregulation, the number

\footnotetext{
${ }^{19}$ Thus, we subtract investments in net working capital from cash flow. The numerator of external financial dependence equals the negative of "free cash flow." Note also that the Compustat items mentioned in the text are only defined for cash flow statements with codes 1, 2, or 3. For format code 7, we use the sum of items \#123, 125,126, 106,213 , and 217.

${ }^{20}$ Size eligibility standards to receive SBA financial support are listed at the SBA Web site: http://www.sba.gov/.
} 
of employees in the firm is smaller than the required SBA threshold level to be eligible for SBA financing, and zero otherwise. Firms immediately above the threshold will not be eligible for SBA financing, and thus will be more financially constrained compared to firms immediately below the threshold. The variable $S B A$ Ineligible is thus defined as one minus $S B A$ Eligible. We also create a Normalized Employment variable which is defined as the firm's total employment in the closest year to the year of the deregulation (used to create the $S B A$ Eligible variable) divided by the SBA employment threshold value for the three-digit NAICS industry of the firm. Note that, by construction, SBA Eligible=1 iff Normalized Employment $<=1$. We also define Log normalized employment as the natural log of Normalized employment. Finally, in our sharp RD analysis, we also use Change in average TFP, which is defined as the difference between the average TFP in the 3 years immediately after the deregulation year and the average TFP in the 3 years immediately preceding the deregulation year in the state of the firm.

\section{How Does Increased Access to Financing Affect Productivity?}

\subsection{Descriptive Statistics}

Panel A of Table 2 reports the summary statistics using the pooled LRD data in our sample. Note that, due to U.S. Census Bureau disclosure requirements, we cannot report median values for our data. We thus report a quasi-median which is the average value of all observations between the 45th and 55th percentile and is very close to the actual median value of each variable. Our sample of LRD firms has a mean asset value of $\$ 10.5$ million and a quasi-median value of $\$ 1.4$ million. Mean sales in our sample is around $\$ 31$ million, whereas quasi-median sales is around $\$ 6$ million. Mean and quasi-median capital expenditure in the sample are around $\$ 801,600$ and $\$ 93,000$ respectively. This capital expenditure reflects both new purchases of capital equipment as well as expenditures incurred for maintenance of existing facilities. These figures, particularly the quasi-median values suggest that our sample includes many small firms, which would potentially be affected more by banking deregulations. We also report the statistics separately for the years before and after the interstate bank branching deregulations in a state. In addition, we report in Table 2, summary statistics for production costs, materials cost, employment, salaries and wages, and Herfindahl index. Panel B of Table 2 reports mean and quasi-median sales values based on sales quintile bins. 
This panel illustrates the substantial heterogeneity in firm size in our data, with the quasi-median sales in the first quintile at $\$ 235,000$ and that for the fifth quintile at $\$ 27.9$ million. Later in the paper, we conduct our TFP analysis for each of this sales bins.

The passing of the IBBEA led to an increase in the number of bank establishments in states due to expansion by out-of-state banks. An increase in bank establishments after deregulation therefore led to an increase in the availability of financing in those states that implemented IBBEA. We start by showing that the deregulation indeed led to an increase in bank branches. We use data from the U.S. Census Bureau's Census of Finance, Insurance, and Real Estate (FIRE) and the Longitudinal Business Database (LBD). The FIRE database (in combination with the LBD) contains bank establishment level data for economic census years (i.e., years ending with 2 or 7 ).

Panel C of Table 2 reports the level of bank establishments in 1987, 1992, 1997, and 2002. ${ }^{21}$ Column (1) of this panel reports the total number of bank establishments in each of the economic census years. We depict these numbers graphically in Figure 1, and overlay this with the number of bank branches and offices data from the FDIC's Historical Statistics of Banking (HSOB). We see that the numbers from the LBD/FIRE data are similar to those from the HSOB data. The number of bank establishments increased substantially from 1987 to 2002 . Columns (2) and (3) report the split of the banking establishments between out-of-state and in-state establishments (which we can obtain from the LBD/FIRE data). As seen in the table and in Figure 1, between 1987 and 1992, the increase in the number of in-state and out-of-state banking establishments are on a roughly parallel path. From 1992 to 2002, the number of in-state bank establishments are, to some extent, decreasing, potentially due to acquisitions by out-of-state banks. The number of in-state bank establishments at the end of $2002(44,568)$ is slightly less than the number of in-state bank establishments in 1987 (46,929), suggesting no growth in this subset of banks. On the other hand, there is substantial growth in the number of out-of-state bank establishments during the period from 1992 to 2002. Moreover, this growth is substantially larger than the decrease in the number of in-state bank establishments, indicating that out-of-state banking establishments grew through both acquisitions and denovo bank branching. This is consistent with a significant increase

\footnotetext{
${ }^{21}$ Note that the FIRE/LBD data have information to compute the state of ownership of a banking unit (which we term as establishment, consistent with the literature using this data). However, it does not allow us to distinguish between denovo branches and BHC-owned branches and offices. All establishments owned by out-of-state entities are grouped together.
} 
in the out-of-state ownership of bank establishments in the late 1990s and early 2000s following the IBBEA.

\subsection{Productivity Changes After Interstate Bank Branching Deregulation}

We use firm-level TFP as a comprehensive measure of productivity and analyze how the TFP of a firm changes after the state in which the firm is located adopts interstate bank branching deregulation brought about by the IBBEA. We employ a firm fixed effects regression framework to analyze these effects. In these regressions, we control for time-varying observable characteristics of the firm and industry as well as year fixed effects. In all regressions, we report standard errors clustered at the state level. ${ }^{22}$ We implement this approach through the following regression specifications:

$$
\begin{gathered}
Y_{i t}=\alpha_{t}+\beta_{i}+\gamma X_{i t}+\delta \text { Deregulation_index } x_{i t}+\varepsilon_{i t} \\
Y_{i t}=\alpha_{t}+\beta_{i}+\gamma X_{i t}+\delta_{1} \text { Before }_{i t}(4,1)+\delta_{2} \text { Deregulation_index } x_{i t}+\varepsilon_{i t}
\end{gathered}
$$

where $Y_{i t}$ is our variable of interest (i.e., firm TFP); $X_{i t}$ is a control for Log assets (where asset is measured as the one year lagged value of total capital stock), Log assets squared, log of firm age, and the one year lagged industry Herfindahl index; Deregulation_index $x_{i t}$ is our main measure of interstate banking deregulation. ${ }^{23}$ In equation (3), we introduce Before ${ }_{i t}(4,1)$, which is a dummy variable that equals one if the year is within four years prior to the interstate bank branching deregulation in the state of the firm and zero otherwise. Conceptually, this variable captures the difference in the TFP for firms between the four years prior to financing deregulation in a state of a firm and the years prior to the four years before the deregulation. ${ }^{24}$ The dynamic pattern of the effect of interstate bank branching deregulation on TFP is captured by the coefficients $\delta^{\prime} s$ in the above equations. In all specifications, $i$ indexes firms, $t$ indexes years, $\beta_{i}$ are firm fixed effects, and $\alpha_{t}$ are year fixed effects. The above specifications are estimated on the entire panel of private firms

\footnotetext{
${ }^{22}$ We also conduct our analyses by clustering on state-year. However, since the Deregulation index is persistent over time, we report the results for regressions clustered by state. We thank the anonymous referee for this suggestion.

${ }^{23}$ Our results remain qualitatively similar if we replace capital stock with total employment as the control variable for size.

${ }^{24}$ This also serves an important part of validating our identification strategy. As noted by Roberts and Whited (2011), this helps in serving as a test for the key assumption in difference-in-difference regressions, namely, that of parallel trends. In this test, the coefficient on the Before $_{i t}(4,1)$ variable should be insignificant from zero.
} 
in the LRD. ${ }^{25}$ We drop variable subscripts $i$ and $t$ in the discussion that follows for parsimony.

Panel A of Table 3 reports the results of our TFP fixed effects regressions. Column (1) reports the results of the basic specification in equation (2). We find that the coefficient estimate on the Deregulation index variable is positive and statistically significant at the 1 percent level. Specifically, the results indicate that a one inter-quartile change in the Deregulation index increases the TFP of a firm by 0.6 percent. As in Schoar (2002), we interpret the economic effect of this coefficient estimate as follows: holding input costs constant, a certain percentage increase in productivity translates to an equal percentage increase in revenues, ceteris paribus. An increase in revenues leads to a more than proportional increase in profits, since the elasticity of profits to productivity is greater than one. Intuitively, an increase in productivity holding all else constant leads to higher revenues without changing costs. For our case, a 0.6 percent increase in TFP corresponds to a 3 percent increase in profits, assuming a 20 percent profit margin. Further, since profits are revenues minus costs, the smaller the profit margin, the higher the elasticity of profits to productivity. Thus, a lower profit margin will actually predict a higher percent increase in profits for a given percent increase in TFP. For instance, reducing the profit margin to 10 percent increases the effect of interstate bank branching deregulation on profits to 6 percent. ${ }^{26}$ Thus, financial deregulation of interstate bank branching has an economically meaningful impact on firm productivity and performance. Moreover, as we document in later sections, this relation is even stronger for smaller and financially constrained firms.

One critique of our methodology is that perhaps our results are driven by states that time their interstate bank branching deregulations to coincide with higher productivity gains. Further, the coefficient estimates on Deregulation index in the previous regressions may simply reflect an increasing TFP trend across all firms. Thus, our argument that these deregulations present an exogenous shift in financing availability needs to be tested. One way that we rule out such timing and trend explanations is by introducing the Before $(4,1)$ dummy variable in Column (2) of Panel A

\footnotetext{
${ }^{25}$ In unreported tests, we find that for the set of publicly traded firms, the coefficient estimate on Deregulation index is not significantly related to TFP, based on model (2). Moreover, the coefficient on Deregulation index is statistically different for coefficients estimated using model (2) for samples of public and private firms.

${ }^{26} \mathrm{~A}$ simple example will help clarify these calculations. Assuming that cost is constant at $\$ 1$ and margin (i.e., profit to sales ratio) is $20 \%$, sales should be $\$ 1.25$. Since a 0.6 percent increase in productivity translates to a 0.6 percent increase in sales, sales should increase by $1.25^{*} 0.006=\$ 0.0075$. Thus, profits also increase by $\$ 0.0075$, since cost is constant. Percentage increase in profits is calculated as $100 *(0.0075 / 0.25)=3 \%$. Using a similar calculation, we can show that percentage change in profits increases as margin decreases.
} 
of Table 3, based on the specification in equation (3) (see, e.g., Bertrand and Mullainathan (2003)). If the deregulations are due to states trying to time productivity or if our results above represent secular trend in productivity, then the coefficient estimate on Before $(4,1)$ should be positive and statistically significant. In Column (2), we find that the coefficient estimate of the Before $(4,1)$ dummy is not statistically significant. This result alleviates concerns that our prior results are driven by reverse causality or trends in TFP.

We also conduct additional tests in this section to ensure that our results in Table 3 are not driven by potential biases in the sample or due to alternative explanations. Black and Strahan (2002) find that greater access to financing leads to more incorporations and Kerr and Nanda (2009) find that increase in financing availability increases new startup activity as well as closures of these newer firms. To rule out the possibility that our results are driven by new firm births after the deregulation of interstate bank branching in various states, we exclude firms born after interstate bank branching deregulations in our first robustness test. The results for this regression are reported in Column (3) of Panel A of Table 3 and are qualitatively similar to our base results. Thus, our TFP results are not driven by new firm births and deaths after financial deregulation.

We also consider the possibility that survivorship bias can affect our results. In particular, if many firms die after the financial deregulation, then the set of firms that survive after deregulation would seem to perform better than the set of firms before deregulation. We can mitigate such a bias by restricting our attention to the sample of firms that survive after deregulation. In Column (4) of Panel A of Table 3, we report the results for the sample of firms where we exclude all firms that die within our sample period which should mitigate any potential survivorship biases in the sample. The results in Column (4) indicate that in this survivorship bias mitigated sample, the effect of Deregulation index on TFP continues to be positive and statistically significant. We also conduct our TFP fixed effects regression using the Deregulation $\&$ reciprocity index, which accounts for the reciprocity requirements imposed by various states when they deregulated interstate bank branching, as the measure of increased access to finance. The result of this regression, reported in Column (5) of Panel A of Table 3 is consistent with those reported above and indicates that a greater extent of interstate bank branching deregulation is associated with an increase in firm TFP.

We also conduct additional robustness checks of the TFP analysis reported above. In order to assess the impact of the deregulation within a short horizon around the law change, we restrict 
our sample for the TFP regression to the time period within five years of the deregulation and find similar results. ${ }^{27}$ The result of this regression, reported in Column (1) of Panel B of Table 3, are consistent with those reported in Panel A of Table 3, that is, Deregulation index is positively related to firm TFP.

We also further address potential reverse causality concerns regarding the passage of interstate bank branching deregulations in the U.S. in this section. If our results reflect a treatment effect of interstate bank branching deregulations by states, then our results should disappear if we falsely assume that our treatment (i.e., interstate bank branching deregulation) occurs one year prior to or one year after the actual deregulation year (see, e.g., Roberts and Whited (2011)). ${ }^{28}$ For these tests, we keep the sample restricted to five years around the actual deregulation year (to assess the impact of the falsification in a finite horizon). Thus, we repeat our TFP regressions under such false definitions of the Deregulation index. Columns (2) and (3) in Panel B of Table 3 report the results of this placebo analysis where the Deregulation index variable is the actual index for one year after to the actual deregulation and one year prior to the actual deregulation, respectively, and zero otherwise. Our results indicate that the coefficient estimate on the falsified Deregulation index is statistically insignificant. The results of this test as well as the insignificant coefficient estimate on the Before $(4,1)$ dummy in Column (2) reassure us that interstate bank branching laws were not implemented to coincide with other unobservable characteristics that would have also boosted firm productivity. Further, these results also provide evidence that reverse causality does not drive our results.

Since TFP is not an accounting measure, and we cannot directly link the TFP of a given firm to its profitability without additional assumptions. One may question whether changes in TFP indeed translate into changes in profitability or changes in output. As a robustness check for our main results, we use alternative measures of performance, including value added per worker or Labor Productivity, which is defined as total sales minus production costs divided by the number of workers; and Sales Growth, which is change in sales from the previous year to the current year divided by the previous year's sales. These measures do not have the desirable theoretical properties of TFP, but they do have familiar statistical properties, since they are not computed

\footnotetext{
${ }^{27}$ Our results are qualitatively similar if we restrict the sample period to within three years of deregulation.

${ }^{28}$ We also conduct the falsification tests by redefining the Deregulation index as that for two years before and after the actual year. Our results remain qualitatively similar to those reported here.
} 
from a regression.

We report the results of the regressions with Labor Productivity and Sales Growth as dependent variables in Columns (4) and (5) in Panel B Table 3 and find similar results to those using TFP. In particular, we find that Labor Productivity and Sales Growth are higher for firms located in states with greater extent of interstate bank branching deregulation. These results, particularly that for Sales Growth, suggests that one potential mechanism through which TFP increases following bank branching deregulation is increased performance due to greater access to more productive and positive NPV projects. We explore this argument in detail in the next section. ${ }^{29}$

\subsection{Financial Constraint and the Effect of Increased Access to Financing on Productivity: Regression Discontinuity Analyses}

We now consider the channel through which increased access to financing leads to greater productivity. We hypothesize that TFP increases after interstate banking deregulations are primarily driven by firms that are financially constrained. Such firms are unable to grow or improve their performance as they are unable to undertake additional productive projects in the absence of adequate financing. However, since the interstate bank branching deregulations lead to an exogenous increase in the availability of financing, firms that are financially constrained will benefit the most following the deregulation, as it would then allow them to take on additional projects thus improving their productivity.

Identification of the impact of financial constraint on the the effect of financing on productivity is achieved by a novel methodology. We distinguish between financially constrained and unconstrained firms using an exogenous discontinuity in the eligibility of firms that can apply for Small Business Administration (SBA) financing. SBA support-eligible firms have access to an additional source of financing, and thus are less financially constrained than non-SBA support-eligible firms. The important identifying assumption here is that firms just above and just below the SBA financing threshold are similar in most respects other than being eligible for SBA financing. This allows

\footnotetext{
${ }^{29}$ We also conduct our TFP regressions using state level controls such as log of GDP, GDP growth, log of state income, $\log$ of state population, $\log$ of state employment, state level TFP, and log of state level capital stock. Moreover, we also control for various controls used in Rice and Strahan (2010), for instance, the relative strength of insurance industry versus the banking industry and the extent of small banks in a state, which might be related to the implementation of interstate bank branching deregulations in that state. Our results after including these various control variables are qualitatively similar to those reported here.
} 
us to compare firms that are unlikely to differ significantly on characteristics other than access to an additional source of financing (SBA financing). As a result, firms that are SBA ineligible (i.e., immediately above the SBA threshold) are more financially constrained relative to firms that are SBA eligible (i.e., immediately below the SBA threshold). Thus, if financial constraints are indeed driving our results, we should find that SBA ineligible firms experience a greater increase in productivity as a result of increased access to financing after the deregulation of interstate bank branching than SBA eligible firms. ${ }^{30}$

\subsubsection{Sharp Regression Discontinuity Analysis}

In this section, we conduct our analysis in a "sharp" regression discontinuity (RD) framework. The advantage of this methodology is that we conduct our analysis using a rigorous and wellestablished RD framework. To do so, however, we have to transform the data in a manner that requires us to give up the cross-state variation of the Deregulation index. ${ }^{31}$ In particular, for each firm, we calculate the change in the average 3-year TFP around the year of the interstate branching deregulation in that firm's state. This variable, as described in the data section, is called Change in average TFP. The sharp RD design thus measures the change in TFP around branching deregulations for SBA ineligible firms compared to the change in TFP for SBA eligible firms (SBA eligibility being our proxy for financial constraint). The sharp RD design we follow has been widely used in the academic literature in the past starting with Thistlewaite and Campbell (1960) to more recent literature such as Lee (2008).

We start by showing how Change in average TFP varies across firms that have Normalized Employment values just above and just below the SBA eligibility threshold. Recall that Normalized Employment is defined as the employment prior to the interstate bank branching deregulation divided by the SBA employment threshold value for the firm's industry. Thus, a firm becomes eligible for SBA financing above the threshold point of 1 for Normalized Employment. Figure 2 reports the results of local polynomial smoothing estimations of Change in average TFP after deregulation on

\footnotetext{
${ }^{30} \mathrm{~A}$ useful feature of this method of identifying financially constrained firms is that we would expect larger firms to be less financially constrained, ceteris paribus. Thus, the "size-effect" of a continuous increase in employment, if any, works against finding a relation between our measure of financial constraint (based on the SBA threshold) and the sensitivity of productivity to access to financing. Further, we control for the continuous version of the size variable in our RD regressions.

${ }^{31}$ We will incorporate the cross-state variation in the Deregulation index using a "quasi" RD design that we describe in the next section.
} 
the Normalized Employment variable around the SBA eligibility threshold point.The figure illustrates our main result in this section. It shows that the Change in average TFP after interstate bank branching deregulation "jumps" up for firms right above the SBA eligibility threshold (which is 1 on the $\mathrm{x}$ axis in the graph). In other words, we see that firms that have relatively fewer alternative financing options experience greater increases in TFP after bank branching deregulation relative to firms that have more financing options. Our non-parametric (local linear estimator) and parametric models described below statistically estimate the jump depicted in the figure.

Figure 3 reports the results of local polynomial smoothing estimations of changes in yearly firm level TFP after deregulation on the Normalized Employment variable around the SBA eligibility threshold point. Rather than using average 3 year TFP change (as in Figure 2) however, we conduct the local polynomial smoothing regressions separately for after and before the first deregulation year for firms just above and just below the SBA threshold. We then subtract the estimators for each normalized employment bin for the "after" deregulation estimators from the "before" deregulation estimators. Figure 3 thus uses using panel (firm-year level) data, whereas Figure 2 using crosssectional (firm level) data. The results from Figure 3 are consistent with that in Figure 2. It shows that the change in yearly TFP after interstate bank branching deregulation "jumps" up for firms right above the SBA eligibility threshold.

We first conduct the RD analysis in a local linear regression framework based on the procedure recommended by Imbens and Lemieux (2008) including the calculation of the optimal bandwidth (based on Imbens and Kalyanaraman (2011). The result of this non-parametric framework is reported in Panel A of Table 4. We find that the Change in average TFP is higher for SBA ineligible firms than for SBA eligible firms (estimate $=0.023$, significant at the 1 percent level). The non-parametric framework estimates the effect of SBA eligibility on TFP change for firms just above and just below the threshold, consistent with the spirit of RD analysis. However, due to the smaller number of observations used, it could be biased.

We then conduct the sharp $\mathrm{RD}$ analysis in a regression framework, where the dependent variable is the Change in average TFP. In addition to Log assets as a size control, we use Log normalized employment and Log normalized employment squared to control for the impact of the continuous assignment variable. Further, we control for year, 3-digit NAICS industry, and state fixed effects in these regressions. In addition, we also control for the average 3-year pre-deregulation TFP. We 
start by conducting this analysis using the sample of firms that is within a 10 percent employment band around the SBA threshold, i.e., for the set of firms with Normalized employment between 0.9 and 1.1 (which we call the 10\% sample). The result of this analysis is reported in Column (1) of Panel B of Table 4. We find that SBA ineligible firms experience a 7.1 percent increase in average productivity following deregulation. This, in turn, corresponds to an increase in profitability of 36 percent (using the methodology from Schoar (2002) discussed earlier). Further, to the extent that firms within a 10 percent band around the SBA threshold are similar in all respects other than the eligibility for SBA funding, our results are unlikely to come from potentially unobservable differences.

We also conduct the above analysis for firms with normalized employment within 30 percent bracket (i.e., the $30 \%$ sample), 50 percent bracket (i.e., the $50 \%$ sample), and the full sample in Columns (2), (3), and (4) of Panel B of Table 4, respectively. Our results are consistent across all specifications, and indicate that SBA ineligible firms experience a greater increase in average TFP around the year of interstate bank branching deregulation.

We proceed to do various robustness checks for the results in Table 4. First, we conduct these regressions controlling for various powers of Log normalized employment for the full sample (Lee and Lemieux (2010)). We also conduct these tests by controlling for interaction terms between $S B A$ ineligible and various powers of Log normalized employment. The results of these tests are reported in Columns (1) to (5) of Table 5, and show that, consistent with prior results, the coefficient estimate on $S B A$ ineligible is positive and statistically significant.

Next, in Table 6, we conduct placebo analyses by moving the discontinuity point by minus 20 percentage points (i.e., discontinuity is falsely specified at Normalized employment of 0.8) and by plus 20 percentage points (i.e., discontinuity is falsely specified at Normalized employment of 1.2). We expect that our results will not show up for the falsified version of these variables. Columns (1) and (2), estimated for the 10\% sample around the falsified thresholds, are consistent with this expectation, supporting our identification of constrained firms using SBA thresholds. ${ }^{32}$

One concern may be that firms may try to obtain federal funding by artificially restricting their size levels to comply with SBA requirements. McCrary (2008) argues that such active sorting may undermine the identification requirements of the regression discontinuity design. To rule out this

\footnotetext{
${ }^{32}$ We also conduct this analysis using $+/-30$ percentage point offset and find similar results as those reported here.
} 
concern, we graphically and statistically analyze the density function of the normalized employment variable around the threshold point. Visual analysis of the density function, reported in Figure 4, indicates a smooth density function of normalized employment at the threshold point. We then conduct the statistical test recommended in McCrary (2008) to ensure that our identification strategy is valid. The test is implemented as a Wald test of the null hypothesis that the discontinuity in the density function of the assignment variable is zero at the threshold point. The test does not find a statistically significant jump or drop in the density function of the normalized employment at the threshold point, thereby validating our identification strategy. ${ }^{33}$

\subsubsection{Quasi-Regression Discontinuity Analysis}

In this section, we use the SBA discontinuity to identify cross-sectional variation in the effect of the treatment (i.e., interstate bank branching deregulations) on the outcome variable (TFP). Since the methodology here interacts a dummy variable for a discrete jump in financial constraint at the predefined SBA threshold with the impact of interstate bank branching deregulation on productivity, we refer to this as the "quasi" regression discontinuity (RD) approach.

We conduct our TFP regression using the sample of firms that is within the $10 \%$ employment band around the SBA threshold. We include interaction terms between Deregulation index and $S B A$ eligible as well as between Deregulation index and $S B A$ ineligible. In addition, we include an interaction term between the Log normalized employment and Deregulation index to control for any impact of the continuous change in employment on the sensitivity of TFP to interstate banking deregulation. The size controls include one year lagged value of Log employment, one year lagged value of Log employment squared, and one year lagged value of Log assets. The results, reported in Column (1) of Table 7, are consistent with those in the previous section. SBA ineligible firms experience a greater increase in TFP than SBA eligible firms if their state deregulates interstate bank branching to a greater extent. In particular, the coefficient estimate on Deregulation index*SBA ineligible is positive and significant while the coefficient estimate on Deregulation index*SBA eligible is insignificant. Economically, a one inter-quartile change in Deregulation index for SBA ineligible firms is associated with a 2 percent increase in TFP. Moreover, the difference in the coefficient

\footnotetext{
${ }^{33}$ The estimator for this test is calculated in two steps. First, one obtains a finely gridded histogram. Second, one smoothes the histogram using local linear regression separately on either side of the cutoff point. The test statistic is based on the estimates of the density function from local linear regressions from the two sides of the cutoff point.
} 
estimates of Deregulation index ${ }^{*} S B A$ ineligible and Deregulation index ${ }^{*} S B A$ eligible is statistically different at the 5 percent level.

In Column (2) of Table 7, we report the tests of the quasi-RD model using the Deregulation $\&$ reciprocity index for the $10 \%$ sample, and find similar results as those in Column (1). We repeat this analysis after restricting the sample to bands of 30 percent and 50 percent around the SBA threshold restriction and find similar results in Columns (3) and (4) of Table 7. Finally, in Column (5) of Table 7, we use the entire sample and find the our main result from Column (1) holds here as well. Thus, our results point to greater financial constraints driving the positive relation between increased availability of financing as a result of interstate bank branching deregulations and firm TFP.

We also conduct various robustness checks for this analysis. First, we test whether our results are robust to various specifications of higher powers of Log employment, as well as the interaction between higher powers of Log normalized employment and Deregulation index. These results are reported in Columns (1) through (4) of Table 8 for the full sample. We find that our results from Table 7 are robust to the specification of the functional form of the assignment variable and employment controls.

Next, in Table 9, we conduct placebo analyses by moving the discontinuity point by minus 20 percentage points and by plus 20 percentage points. We expect that our results will not show up for the falsified version of these variables. Columns (1) and (2), estimated for the $10 \%$ bracket around the falsified thresholds, are consistent with this expectation, supporting our identification of financially constrained firms using SBA thresholds. ${ }^{34}$

\subsection{Financial Constraint and the Effect of Increased Access to Financing on Productivity: Firm Size Interaction Tests}

Firm size has been used as a proxy for financial constraint, as smaller firms typically face a greater number of constraints in sourcing capital. Thus, we analyze whether our results documenting TFP gains after interstate bank branching deregulations vary based on firm size. We use various proxies for firm size including sales (i.e., total value of shipments), assets (capital stock), and employment. We divide our sample by size quintile bins based on these measures and report our regression results

\footnotetext{
${ }^{34}$ We also conduct this analysis using $+/-30$ percentage point offset and find similar results as those reported here.
} 
in Table 10. The size variable used to classify firms in the size quintile bins is measured as of the closest year prior to the interstate bank branching deregulation in the state of the firm. Thus, we only use the set of firms that exist in the sample prior to deregulation for these tests. We then run our TFP regressions with Deregulation index interacted with a dummy variable for each of the five size quintiles. We name the dummy variables for size quintiles as Size quintile 1 to Size quintile 5, where the former refers to the smallest size quintile and the latter refers to the largest.

Panel A of Table 10 report the regression results for size quintile bins based on sales. In Column (1) in Panel A of Table 10, the coefficient estimate on Deregulation index* Size quintile 1 is economically large and statistically significant at the 1 percent level. The economic magnitude suggests that the TFP for small firms increases by 5.4 percent for a one inter-quartile range increase in interstate bank branching deregulations. Using the methodology for interpreting changes in productivity as changes in profitability (described earlier), this change in TFP corresponds to a 27 percent increase in profits. The coefficient estimates on Deregulation index*Size Quintile 2, Deregulation index*Size Quintile 3, Deregulation index*Size Quintile 4, and Deregulation index*Size Quintile 5 variables are considerably smaller and statistically different than that for Deregulation index*Size Quintile 1 (0.008, 0.004, 0.002, and 0.003 vs. 0.027, respectively). The difference between the coefficient estimates on Deregulation index*Size Quintile 1 and Deregulation index*Size Quintile 5 is statistically significant at the 1 percent level. Column (2) of Panel A, Table 10 reports the results of these regressions using the Deregulation 8 reciprocity index, which incorporates the effect of the reciprocity requirement. The results in this regression are similar to those in Column (1).

Our results are similar when we repeat these tests with size bins based on assets. In Columns (3) and (4) of Panel A of Table 10, using size bins defined using total assets, we again find that the TFP of smaller firms increases substantially more than that of larger firms after the deregulation of interstate bank branching. We also conduct our size-based interaction tests based on employment bins using the following cutoffs: 1 to 10 employees, 11 to 20 employees, 21 to 50 employees, 51 to 100 employees, and greater than 100 employees. We interact Deregulation index with each of these employment bins. Panel B of Table 10 reports the results with the employment bins. We find that our results mirror the results using total value of shipments and capital stock. Smaller firms by employment experience a greater increase in TFP after the deregulation of interstate bank branching. In particular, Column (1) indicates that, economically, smaller firms (i.e., those with 10 
employees or less) experience a 1.6 percent increase in productivity for a one inter-quartile increase in Deregulation index, which corresponds to a 8 percent increase in profits; whereas large firms (i.e., those with greater than 101 employees) experience a 0.6 percent increase in productivity, which corresponds to a 3 percent increase in profits. The difference between the coefficient estimate of Deregulation index $*(E m p>=1 \&<=10)$ with that of Deregulation index ${ }^{*}(E m p>=101)$ is statistically significant at the 5 percent level. Further, as reported in Column (2), our results are similar when we interact the Deregulation $\mathcal{E}$ reciprocity index with each employment bin dummy. In particular, smaller firms by employment have a greater increase in TFP compared to larger firms after interstate bank branching deregulations.

In summary, the results in this section suggest that smaller (and thus more financially constrained) firms gain substantially more from greater access to financing as a result of interstate bank branching deregulations than larger (and less financially constrained) firms. We use three different proxies for size, i.e., sales, assets, and employment, and find that our results hold for all three size proxies.

\subsection{Financial Constraint and the Effect of Increased Access to Financing on Productivity: External Financial Dependence of Industry Interaction Tests}

We also use the measure of external financial dependence based on industry accounting variables used in Rajan and Zingales (1998) and Cetorelli and Strahan (2006) to further analyze how the effect of greater access to financing on firm TFP varies with financial constraints. Thus, we interact Deregulation index in our TFP regressions with the High External Financial Dependence dummy for the firm's industry. We also include Deregulation index interacted with a Low External Financial Dependence dummy variable. The Low External Financial Dependence dummy is defined as one minus the High External Financial Dependence dummy.

The results of the interaction tests are reported in Column (1) of Table 11 and support the inference from the results in the previous two subsections. In particular, while both interaction terms have positive and significant coefficient estimates, the estimate on Deregulation index*High External Financial Dependence is economically and statistically larger than that on Deregulation index*Low External Financial Dependence. The results suggest that firms in highly financially constrained industries have a 1.6 percent increase in TFP, whereas those in less financially constrained 
industries have a 0.6 percent increase in TFP for a one inter-quartile range increase in interstate

bank branching. Further, as reported in Column (2), our results are similar when we interact the Deregulation $\&$ reciprocity index with the High External Financial Dependence and Low External Financial Dependence dummies. The results here provide further support to the idea that greater access to financing allows financially constrained firms to implement more productive and higher NPV projects.

\section{Conclusion}

We analyze how increased access to financing affects firm productivity using a large sample of manufacturing firms obtained from the U.S. Census Bureau's Longitudinal Research Database (LRD). We exploit the exogenous shift in access to financing due to interstate bank branching deregulations that took place in the 1990s and relate these deregulations to firm level total factor productivity (TFP). Our results indicate that firms' productivity increased subsequent to their states allowing out-of-state banks to establish local bank branches. We find that firms that are close to but do not satisfy eligibility criteria for financial support from the U.S. Small Business Administration (and thus more financially constrained) have higher TFP increases after bank branching deregulation and in states with a greater extent of bank branching deregulation than firms that just satisfy eligibility criteria (less financially constrained). TFP increases after bank branching deregulation is greater for firms that are financially constrained, such as smaller firms and firms that are in more financially constrained industries (based on Rajan and Zingales (1998)). Our results support the idea that greater access to financing may increase a financially constrained firms' access to additional productive projects that they may otherwise not be able to take up. Our results emphasize that availability of financing is important not only for startup activity (as prior research suggests), but also for the success of existing entrepreneurial and small firms.

This study contributes to the existing literature by analyzing the real performance effects of increased access to financing. Our analysis of the intensive margin of firm-level outcomes (i.e., productivity) is useful to understand the economic consequences of both increasing access to financing as well as financial deregulation on existing firms. Our results suggest that increased access to bank financing allows smaller and financially constrained firms to take up real investment opportunities 
that they may not otherwise be able to have access to. In particular, we show that such increased access to financing increases their productivity. This is crucial from a policy perspective if the objective is to promote the growth of startups especially given that most small firms rely heavily on bank financing. 


\section{References}

[1] Bartelsman, E. J., and W. Gray, 1996, The NBER Manufacturing Productivity Database. Technical Working Paper, National Bureau of Economic Research.

[2] Bertrand M., A. Schoar, and D. Thesmar, 2007, Banking deregulation and industry structure: evidence from the French banking reforms of 1985. Journal of Finance 62:597-628.

[3] Bertrand M. and S. Mullainathan, 2003, Enjoying the Quiet Life? Corporate Governance and Managerial Preferences, Journal of Political Economy 111:1043-075.

[4] Black, S. E. and P. E. Strahan, 2002, Entrepreneurship and Bank Credit Availability. Journal of Finance 57:2807-2833.

[5] Butler, A. W. and J. Cornaggia, 2011, Does Access to External Finance Improve Productivity? Evidence from a Natural Experiment, Journal of Financial Economics, Vol. 99, Issue 1, January, pp. 184-203.

[6] Cetorelli, N. and P. E. Strahan, 2006, Finance as a barrier to entry: bank competition and industry structure in local US markets. Journal of Finance 61: 437-461.

[7] Chemmanur, T. J., S. He, and D. Nandy, 2010, The Going Public Decision and the Product Market. Review of Financial Studies 23:1855-1908.

[8] Chemmanur, T. J., K. Krishnan, and D. Nandy, 2011, How Does Venture Capital Financing Improve Efficiency in Private Firms? A Look Beneath the Surface. Review of Financial Studies 24:4037-4090.

[9] Denis, D., and McKeon, S., 2012, Debt Financing and Financial Flexibility: Evidence from Pro-Active Leverage Increases, Review of Financial Studies 26:1897-1929.

[10] Denis, D., and Sibilkov, V., 2010, Financial Constraints, Investment, and the Value of Cash Holdings, Review of Financial Studies 23:247-269.

[11] Fazzari, S. M., R. G. Hubbard, and B. C. Peterson, 1988, Financing constraints and corporate investment. Brookings Papers on Economic Activity 1:141-195. 
[12] Fracassi, C., M. J. Germaise, S. Kogan, and G. Natividad, 2013, Business microloans for U.S. subprime borrowers, Working paper, UT Austin and UCLA.

[13] Guiso, L., P. Sapienza, and L. Zingales, 2004, Does local financial development matter? Quarterly Journal of Economics 119:929-969.

[14] Hicks, John. R., 1969. A Theory of Economic History. Oxford, Calderon Press.

[15] Imbens, G. W., and T. Lemieux, 2008, Regression discontinuity designs: A guide to practice, Journal of Econometrics 142:615-635.

[16] Imbens, G. W., and K. Kalyanaraman, 2012, Optimal bandwidth choice for the regression discontinuity estimator, Review of Economic Studies 79:933-959.

[17] Jayaratne, J., and P. E. Strahan, 1996, The finance-growth nexus: evidence from bank branch deregulation. Quarterly Journal of Economics 111:639-670.

[18] Johnson, C., and T. Rice, 2008, Assessing a decade of interstate bank branching, The Washington and Lee Law Review 65:73-127.

[19] Kaplan, S. N., and L. Zingales, 1997, Do investment-cash flow sensitivities provide useful measures of financing constraints? Quarterly Journal of Economics 112:169-215.

[20] Kaplan, S. N., and L. Zingales, 2000, Investment-cash flow sensitivities are not valid measures of financing constraints. Quarterly Journal of Economics 115: 707-712.

[21] Kerr, W. R., and R. Nanda, 2009, Democratizing Entry: Banking Deregulations, Financing Constraints, and Entrepreneurship. Journal of Financial Economics 94:124-49.

[22] Kerr, W. R., J. Lerner, and A. Schoar, 2013, The Consequences of Entrepreneurial Finance: Evidence from Angel Financings. Review of Financial Studies, forthcoming.

[23] Lee, D. S., 2008, Randomized Experiments from Non-Random Selection in U.S. House Elections, Journal of Econometrics 142:675-697

[24] Lee, D. S., and T. Lemieux, 2010, Regression discontinuity designs in economics, Journal of Economic Literature 48:281-355. 
[25] Levine, R., N. Loayza, and T. Beck, 2000, Financial intermediation and growth: causality and causes. Journal of Monetary Economics 46:31-77.

[26] Levinsohn, J. and A. Petrin, 2003, Estimating Production Functions Using Inputs to Control for Unobservables, Review of Economic Studies 70:317-341.

[27] Lichtenberg, F. R., 1992, Corporate Takeovers and Productivity. Cambridge, MA: MIT Press.

[28] Lichtenberg, F. R., and D. Siegel, 1990, The Effect of Leveraged Buyouts on Productivity and Related Aspects of Firm Behavior. Journal of Financial Economics 27:165-94.

[29] Maksimovich, V., G. Phillips, and N.R. Prabhala, 2011, Post-merger restructuring and the boundaries of the firm, 2011, Journal of Financial Economics 102:317-343.

[30] McCrary, J. 2008. Manipulation of the Running Variable in the Regression Discontinuity Design: A Density Test. Journal of Econometrics 142:698-714.

[31] McGuckin, R. H., and S. Nguyen, 1995, On Productivity and Plant Ownership Change: New Evidence from the Longitudinal Research Database. Rand Journal of Economics 26:257-76.

[32] McGuckin, R. H., and G. Pascoe, 1988, The Longitudinal Research Database: Status and Research Possibilities. Survey of Current Business 68:30-7.

[33] Moyen, N., 2004, Investment-cash flow sensitivities: constrained versus unconstrained firms. Journal of Finance 59: 2061-2092.

[34] Olley, S. and A. Pakes, 1996, The Dynamics of Productivity in the Telecommunications Equipment Industry, Econometrica 64:1263-1298.

[35] Puri, M., and R. Zarutskie, 2012, On the Lifecycle Dynamics of Venture-Capital and NonVenture-Capital-Financed Firms. Journal of Finance 67:2247-93.

[36] Rajan, R.G., and L. Zingales, 1998, Financial dependence and growth. American Economic Review 88:559-586.

[37] Rice, T. and P. E. Strahan, 2010, Does Credit Competition Affect Small-Firm Finance?, Journal of Finance 65:861-889. 
[38] Robb, A. and D. Robinson, 2013, The Capital Structure Decisions of New Firms, Review of Financial Studies, forthcoming.

[39] Roberts M. R., and T. M. Whited, 2011, Endogeneity in Empirical Corporate Finance, Elsevier.

[40] Robinson, J., 1952, The Generalization of the General Theory, In: the Rate of Interest and Other Essays, London, MacMillan.

[41] Schoar, A, 2002, Effects of Corporate Diversification on Productivity, Journal of Finance $57: 2379-403$.

[42] Thistlethwaite, D., and D. Campbell, 1960, Regression-discontinuity analysis: an alternative to the ex post facto experiment, Journal of Educational Psychology 51:309-317. 


\section{Table 1: Interstate Bank Branching Laws by States}

This table reports the changes in interstate bank branching laws in the U.S. from 1994 to 2005. This data is from Johnson and Rice (2008). The effective date of the state's setting of interstate bank branching restrictions allowed under the Interstate Banking and Branching Efficiency Act (IBBEA) is in the first column, with some states having multiple effective dates as they imposed or removed restrictions gradually. The next five columns then report the actual restrictions set by each state as of each effective date.

\begin{tabular}{|c|c|c|c|c|c|c|}
\hline State & $\begin{array}{c}\text { Effective } \\
\text { Date }\end{array}$ & $\begin{array}{l}\text { Age } \\
\text { restriction }\end{array}$ & $\begin{array}{c}\text { De novo interstate } \\
\text { branching restriction } \\
\text { (Yes = State restricts } \\
\text { de novo interstate } \\
\text { branching) }\end{array}$ & $\begin{array}{c}\text { Individual branch } \\
\text { acquisition restriction } \\
\text { (Yes = State does not } \\
\text { allow acquisition of } \\
\text { branches) }\end{array}$ & $\begin{array}{l}\text { Statewide } \\
\text { cap on } \\
\text { deposits } \\
\text { restriction }\end{array}$ & $\begin{array}{l}\text { Reciprocity } \\
\text { requirement }\end{array}$ \\
\hline Alabama & 5/31/1997 & 5 & Yes & Yes & $30 \%$ & No \\
\hline Alaska & 1/1/1994 & 3 & Yes & No & $50 \%$ & No \\
\hline Arizona & 8/31/2001 & 5 & Yes & No & $30 \%$ & Yes \\
\hline Arizona & 9/1/1996 & 5 & Yes & Yes & $30 \%$ & Yes \\
\hline Arkansas & 6/1/1997 & 5 & Yes & Yes & $25 \%$ & No \\
\hline California & 9/28/1995 & 5 & Yes & Yes & $30 \%$ & No \\
\hline Colorado & 6/1/1997 & 5 & Yes & Yes & $25 \%$ & No \\
\hline Connecticut & 6/27/1995 & 5 & No & No & $30 \%$ & Yes \\
\hline Delaware & 9/29/1995 & 5 & Yes & Yes & $30 \%$ & No \\
\hline DC & 6/13/1996 & No & No & No & $30 \%$ & No \\
\hline Florida & 6/1/1997 & 3 & Yes & Yes & $30 \%$ & No \\
\hline Georgia & $5 / 10 / 2002$ & 3 & Yes & Yes & $30 \%$ & No \\
\hline Georgia & 6/1/1997 & 5 & Yes & Yes & $30 \%$ & No \\
\hline Hawaii & $1 / 1 / 2001$ & No & No & No & $30 \%$ & No \\
\hline Hawaii & 6/1/1997 & 5 & Yes & Yes & $30 \%$ & No \\
\hline Idaho & 9/29/1995 & 5 & Yes & Yes & No & Yes \\
\hline Illinois & $8 / 20 / 2004$ & No & No & No & $30 \%$ & Yes \\
\hline Illinois & 6/1/1997 & 5 & Yes & Yes & $30 \%$ & No \\
\hline Indiana & 7/1/1998 & 5 & No & No & $30 \%$ & Yes \\
\hline Indiana & 6/1/1997 & No & No & No & $30 \%$ & Yes \\
\hline Iowa & 4/4/1996 & 5 & Yes & Yes & $15 \%$ & No \\
\hline Kansas & 9/29/1995 & 5 & Yes & Yes & $15 \%$ & No \\
\hline Kentucky & $3 / 22 / 2004$ & No & Yes & Yes & $15 \%$ & Yes \\
\hline Kentucky & $3 / 17 / 2000$ & No & Yes & Yes & $15 \%$ & No \\
\hline Kentucky & 6/1/1997 & 5 & Yes & Yes & $15 \%$ & No \\
\hline Louisiana & 6/1/1997 & 5 & Yes & Yes & $30 \%$ & No \\
\hline Maine & 1/1/1997 & No & No & No & $30 \%$ & Yes \\
\hline Maryland & 9/29/1995 & No & No & No & $30 \%$ & No \\
\hline Massachusetts & 8/2/1996 & 3 & No & No & $30 \%$ & Yes \\
\hline Michigan & 11/29/1995 & No & No & No & No & Yes \\
\hline Minnesota & 6/1/1997 & 5 & Yes & Yes & $30 \%$ & No \\
\hline Mississippi & 6/1/1997 & 5 & Yes & Yes & $25 \%$ & No \\
\hline Missouri & 9/29/1995 & 5 & Yes & Yes & $13 \%$ & No \\
\hline
\end{tabular}




\begin{tabular}{|c|c|c|c|c|c|c|}
\hline Montana & $10 / 1 / 2001$ & 5 & Yes & Yes & $22 \%$ & No \\
\hline Montana & 9/29/1995 & N/A & & & $\begin{array}{l}\text { Increases } \\
1 \% \text { per } \\
\text { year } \\
\text { from } 18 \% \\
\text { to } 22 \%\end{array}$ & No \\
\hline Nebraska & 5/31/1997 & 5 & Yes & Yes & $14 \%$ & No \\
\hline Nevada & 9/29/1995 & 5 & Limited & Limited & $30 \%$ & No \\
\hline $\begin{array}{l}\text { New } \\
\text { Hampshire }\end{array}$ & $1 / 1 / 2002$ & No & No & No & $30 \%$ & Yes \\
\hline $\begin{array}{l}\text { New } \\
\text { Hampshire }\end{array}$ & 8/1/2000 & 5 & No & No & $30 \%$ & Yes \\
\hline $\begin{array}{l}\text { New } \\
\text { Hampshire }\end{array}$ & 6/1/1997 & 5 & Yes & Yes & $20 \%$ & No \\
\hline New Jersey & 4/17/1996 & No & Yes & No & $30 \%$ & No \\
\hline New Mexico & 6/1/1996 & 5 & Yes & Yes & $40 \%$ & No \\
\hline New York & 6/1/1997 & 5 & Yes & No & $30 \%$ & No \\
\hline North Carolina & 7/1/1995 & No & No & No & $30 \%$ & Yes \\
\hline North Dakota & 8/1/2003 & No & No & No & $25 \%$ & Yes \\
\hline North Dakota & 5/31/1997 & No & Yes & Yes & $25 \%$ & Yes \\
\hline Ohio & 5/21/1997 & No & No & No & $30 \%$ & No \\
\hline Oklahoma & $5 / 17 / 2000$ & No & No & No & $20 \%$ & Yes \\
\hline Oklahoma & 5/31/1997 & 5 & Yes & Yes & $15 \%$ & No \\
\hline Oregon & 7/1/1997 & 3 & Yes & Yes & $30 \%$ & No \\
\hline Pennsylvania & 7/6/1995 & No & No & No & $30 \%$ & Yes \\
\hline Rhode Island & 6/20/1995 & No & No & No & $30 \%$ & Yes \\
\hline South Carolina & 7/1/1996 & 5 & Yes & Yes & $30 \%$ & No \\
\hline South Dakota & 3/9/1996 & 5 & Yes & Yes & $30 \%$ & No \\
\hline Tennessee & $3 / 17 / 2003$ & 3 & No & No & $30 \%$ & Yes \\
\hline Tennessee & 7/1/2001 & 5 & No & No & $30 \%$ & Yes \\
\hline Tennessee & 5/1/1998 & 5 & Yes & No & $30 \%$ & Yes \\
\hline Tennessee & 6/1/1997 & 5 & Yes & Yes & $30 \%$ & Yes \\
\hline Texas & 9/1/1999 & No & No & No & $20 \%$ & Yes \\
\hline Texas & 8/28/1995 & N/A & $\mathrm{N} / \mathrm{A}$ & N/A & $20 \%$ & N/A \\
\hline Utah & 4/30/2001 & 5 & No & No & $30 \%$ & Yes \\
\hline Utah & 6/1/1995 & 5 & Yes & No & $30 \%$ & No \\
\hline Vermont & $1 / 1 / 2001$ & No & No & No & $30 \%$ & Yes \\
\hline Vermont & 5/30/1996 & 5 & Yes & No & $30 \%$ & No \\
\hline Virginia & 9/29/1995 & No & No & No & $30 \%$ & Yes \\
\hline Washington & 5/9/2005 & 5 & No & No & $30 \%$ & Yes \\
\hline Washington & 6/6/1996 & 5 & Yes & Yes & $30 \%$ & No \\
\hline West Virginia & 5/31/1997 & No & No & No & $25 \%$ & Yes \\
\hline Wisconsin & 5/1/1996 & 5 & Yes & Yes & $30 \%$ & No \\
\hline Wyoming & 5/31/1997 & 3 & Yes & Yes & $30 \%$ & No \\
\hline
\end{tabular}




\section{Table 2: Summary Statistics}

This table reports summary statistics for firms in the manufacturing sector in the LRD between 1976 and 2005. Panel A reports pooled summary statistics for the time period before the interstate bank branching deregulation in a state ("Before") and after the interstate bank branching deregulation in a state ("After"). Assets is constructed via the perpetual inventory method and is the sum of building assets plus machinery assets. Sales is the total value of shipments. Production Cost sum of materials cost plus rental and administrative expenditures. Total capital expenditure is the dollar value the firm spends on the purchase and maintenance of plant, machinery, and equipment, etc. Materials Cost is the expenses for the cost of materials and parts purchased, resales, contract work, and fuel and energy purchased. Age is the number of years since the firm first appeared in the LRD sample. Salaries and wages is the total production-worker wages plus total non-production-worker wages plus total supplemental labor costs, which include both legally required supplemental labor costs as well as voluntary supplemental labor costs of the firms. Herfindahl index is the extent of industry concentration measured by summing up the square of each firm's market share (in sales) at the annual three-digit NAICS level. Panel B reports sales statistics by sales quintile bins. Panel C reports the number of bank establishments in four census years (years ending in 2 or 7) in the U.S., as well as the number of out-of-state bank establishments and the number of in-state bank establishments. This panel uses data from the FIRE census and the LBD. To comply with the U.S. Census Bureau confidentiality requirements, we report QuasiMedians which are the average of all observations between the $45^{\text {th }}$ and the $55^{\text {th }}$ percentile for each variable. All observations are at the firm-year level. Where relevant, figures are in thousands of dollars.

\begin{tabular}{llrrr}
\hline Panel A: Pooled sample statistics & & & \\
\hline \multirow{2}{*}{ Assets } & & Overall & Before & After \\
& Mean & 10458.690 & 13592.096 & 8529.844 \\
& Qmedian & 1421.938 & 1519.124 & 1365.300 \\
Sales & Count & 570596 & 217411 & 353185 \\
& Mean & 31054.170 & 41917.789 & 24366.828 \\
Production cost & Qmedian & 6029.849 & 6797.553 & 5620.406 \\
& Count & 570596 & 217411 & 353185 \\
Total capital expenditure & Mean & 15623.600 & 20954.643 & 12341.964 \\
& Qmedian & 2687.164 & 3053.341 & 2489.982 \\
& Count & 570596 & 217411 & 353185 \\
Materials cost & Mean & 801.614 & 958.952 & 704.761 \\
& Qmedian & 93.001 & 109.230 & 83.730 \\
& Count & 570596 & 217411 & 353185 \\
Employment & Mean & 19915.640 & 29164.237 & 14222.451 \\
& Qmedian & 2321.423 & 2430.627 & 2257.122 \\
Herfindahl index & Count & 570596 & 217411 & 353185 \\
& Mean & 195.566 & 218.410 & 181.503 \\
& Qmedian & 64.292 & 62.856 & 65.278 \\
& Count & 570596 & 217411 & 353185 \\
& Mean & 0.018 & 0.016 & 0.020 \\
& Qmedian & 0.012 & 0.011 & 0.013 \\
& Count & 570596 & 217411 & 353185 \\
& Mean & 4659.628 & 5284.689 & 4274.858 \\
& Qmedian & 1339.898 & 1370.314 & 1321.518 \\
& Count & 570596 & 217411 & 353185 \\
\hline \multirow{3}{*}{ Salaries and wages } & & &
\end{tabular}




\begin{tabular}{cccc}
\hline \multicolumn{4}{l}{ Panel B: Sales values by sales quintile bins } \\
\hline Sales quintile & Mean & Quasi-median & Count \\
\hline 1 & 4224.782 & 235.09 & 7806 \\
2 & 1366.741 & 518.787 & 20295 \\
3 & 2644.923 & 1488.27 & 38754 \\
4 & 7186.721 & 4879.323 & 76081 \\
5 & 84616.13 & 27946.17 & 151504 \\
\hline
\end{tabular}

\begin{tabular}{lccc}
\hline \multicolumn{4}{c}{ Panel C: Total bank establishments across census years (LBD/FIRE data) } \\
\hline & $(1)$ & $(2)$ & $(3)$ \\
\hline & Total number & Out-of-state & of \\
Year & bank & $\begin{array}{c}\text { In-state } \\
\text { bank }\end{array}$ \\
\hline 1987 & 54029 & 7100 & 46929 \\
1992 & 66337 & 12149 & 54188 \\
1997 & 69447 & 21299 & 48148 \\
2002 & 79246 & 34678 & 44568 \\
\hline
\end{tabular}


Table 3: TFP changes Around Interstate Bank Branching Deregulations

This table reports results for panel data regressions where the dependent variable is the TFP of a firm for a given year (winsorized at the one percent level). The independent variables are: Deregulation Index is an index that is one for the state that has the most restrictive interstate bank branching regulations as of the effective date of the state's setting of interstate bank branching restrictions, and increases by one for each restriction that is relaxed by a state (this index takes the value zero in all years prior to the effective date); Before $(4,1)$, which is a dummy variable that equals one for years -4 to -1 relative to the deregulation of interstate bank branching in the firm's state, and zero otherwise; Log assets, which is the natural log of the one year lagged value of the firm's capital stock; Log assets; Log age, which is the natural logarithm of firm age; Herfindahl index, which is the one year lagged concentration of the firm's three digit NAICS industry (winsorized at the one percent level); and firm and year fixed effects. The various specifications in Panel A are as follows. Column (1) reports the basic specification. Column (2) reports the regression results by including Before $(4,1)$ as a control variable. Column (3) excludes firms born after interstate bank branching deregulations are implemented in a firm's state. Column (4) excludes firms that are categorized in the US Census Bureau Business Register as dying within our sample period. Column (5) reports the results when Deregulation index is modified by adding one for states that do not impose a reciprocity requirement in their interstate banking regulations. The various specifications in Panel B are as follows. Column (1) restricts the sample to within 5 years before and after interstate bank branching deregulations are implemented in a firm's state. Columns (2) and (3) falsify Deregulation index to be the value for one year after (thus moving the deregulation one year before) and one year before (thus moving the deregulation one year after) the current year, respectively The samples in these columns are restricted to within five years of the falsified deregulation year. Columns (4) and (5) report the results for specifications where the dependent variables are labor productivity and sales growth, respectively. Heteroskedasticity corrected robust standard errors, which are clustered by state, are in brackets. All regressions are estimated with an intercept term. ${ }^{* * *},{ }^{* *}$, and $*$ represent statistical significance at the 1,5 , and 10 percent levels, respectively.

\begin{tabular}{|c|c|c|c|c|c|}
\hline \multicolumn{6}{|l|}{ Panel A } \\
\hline & $\begin{array}{c}\text { Basic } \\
\text { specification }\end{array}$ & $\begin{array}{l}\text { Controlling } \\
\text { for } \\
\text { Before }(4,1)\end{array}$ & $\begin{array}{l}\text { Exclude firms } \\
\text { born after } \\
\text { deregulation of } \\
\text { interstate bank } \\
\text { branching } \\
\end{array}$ & $\begin{array}{l}\text { Exclude } \\
\text { firms } \\
\text { categorized } \\
\text { as Death in } \\
\text { LBD } \\
\end{array}$ & $\begin{array}{l}\text { Deregulation } \\
\text { \& reciprocity } \\
\text { index }\end{array}$ \\
\hline & (1) & (2) & (3) & (4) & (5) \\
\hline Deregulation index & $\begin{array}{c}0.003 * * * \\
{[0.001]}\end{array}$ & $\begin{array}{c}0.004 * * * \\
{[0.001]}\end{array}$ & $\begin{array}{c}0.003^{* * *} \\
{[0.001]}\end{array}$ & $\begin{array}{c}0.003^{* * *} \\
{[0.001]}\end{array}$ & $\begin{array}{c}0.003^{* * *} \\
{[0.001]}\end{array}$ \\
\hline Before $(4,1)$ & & $\begin{array}{c}0.003 \\
{[0.002]}\end{array}$ & & & \\
\hline Log assets & $\begin{array}{c}-0.068^{* * *} \\
{[0.006]}\end{array}$ & $\begin{array}{c}-0.068^{* * *} \\
{[0.006]}\end{array}$ & $\begin{array}{c}-0.071^{* * *} \\
{[0.006]}\end{array}$ & $\begin{array}{c}-0.074 * * * \\
{[0.006]}\end{array}$ & $\begin{array}{c}-0.068^{* * *} \\
{[0.006]}\end{array}$ \\
\hline $\log _{\text {assets }}^{2}$ & $\begin{array}{c}0.003 * * * \\
{[0.000]}\end{array}$ & $\begin{array}{c}0.003^{* * *} \\
{[0.000]}\end{array}$ & $\begin{array}{c}0.003^{* * *} \\
{[0.000]}\end{array}$ & $\begin{array}{c}0.003^{* * *} \\
{[0.000]}\end{array}$ & $\begin{array}{c}0.003^{* * *} \\
{[0.000]}\end{array}$ \\
\hline Log age & $\begin{array}{c}-0.006 \\
{[0.004]}\end{array}$ & $\begin{array}{c}-0.006 \\
{[0.004]}\end{array}$ & $\begin{array}{c}-0.000 \\
{[0.005]}\end{array}$ & $\begin{array}{c}0.003 \\
{[0.005]}\end{array}$ & $\begin{array}{c}-0.006 \\
{[0.004]}\end{array}$ \\
\hline Herfindahl index & $\begin{array}{c}0.292 * * * \\
{[0.106]}\end{array}$ & $\begin{array}{c}0.292 * * * \\
{[0.106]}\end{array}$ & $\begin{array}{c}0.284 * * * \\
{[0.105]}\end{array}$ & $\begin{array}{c}0.370 * * * \\
{[0.126]}\end{array}$ & $\begin{array}{c}0.291 * * * \\
{[0.106]}\end{array}$ \\
\hline Firm and Year FE & $\mathrm{Y}$ & $\bar{Y}$ & $\mathrm{Y}$ & $\bar{Y}$ & $\mathrm{Y}$ \\
\hline Observations & 570596 & 570596 & 558881 & 336977 & 570596 \\
\hline Number of firms & 137009 & 137009 & 130701 & 62152 & 137009 \\
\hline Adj. R-sq. & 0.517 & 0.517 & 0.515 & 0.495 & 0.517 \\
\hline
\end{tabular}




\begin{tabular}{|c|c|c|c|c|c|}
\hline \multicolumn{6}{|l|}{ Panel B } \\
\hline & $\begin{array}{l}\text { Sample } \\
\text { restricted to } \\
\text { within } 5 \\
\text { years around } \\
\text { law change }\end{array}$ & $\begin{array}{c}\text { Placebo test: } \\
\text { Deregulation falsified } \\
\text { to one year before } \\
\text { actual deregulation } \\
\text { year } \\
\text { (Sample restricted to } \\
\text { within } 5 \text { years around } \\
\text { placebo law year) }\end{array}$ & $\begin{array}{c}\text { Placebo test: } \\
\text { Deregulation falsified } \\
\text { to one year after } \\
\text { actual deregulation } \\
\text { year } \\
\text { (Sample restricted to } \\
\text { within } 5 \text { years around } \\
\text { placebo law year) }\end{array}$ & $\begin{array}{l}\text { Dependent } \\
\text { variable: } \\
\text { Labor } \\
\text { productivity }\end{array}$ & $\begin{array}{l}\text { Dependent } \\
\text { variable: } \\
\text { Sales } \\
\text { growth }\end{array}$ \\
\hline & (1) & (2) & (3) & (4) & (5) \\
\hline Deregulation index & $\begin{array}{l}0.002^{*} \\
{[0.001]}\end{array}$ & $\begin{array}{c}0.002 \\
{[0.001]}\end{array}$ & $\begin{array}{c}0.002 \\
{[0.001]}\end{array}$ & $\begin{array}{c}7.516^{* * *} \\
{[0.879]}\end{array}$ & $\begin{array}{c}0.011^{* * *} \\
{[0.002]}\end{array}$ \\
\hline Log assets & $\begin{array}{c}-0.043^{* * *} \\
{[0.007]}\end{array}$ & $\begin{array}{c}-0.038^{* * *} \\
{[0.007]}\end{array}$ & $\begin{array}{c}-0.049 * * * \\
{[0.006]}\end{array}$ & $\begin{array}{c}-118.767 * * * \\
{[21.119]}\end{array}$ & $\begin{array}{c}-0.112 * * * \\
{[0.011]}\end{array}$ \\
\hline Log assets ${ }^{2}$ & $\begin{array}{c}0.001 * * * \\
{[0.001]}\end{array}$ & $\begin{array}{l}0.001^{* *} \\
{[0.001]}\end{array}$ & $\begin{array}{c}0.002^{* * *} \\
{[0.000]}\end{array}$ & $\begin{array}{c}10.404^{* * *} \\
{[1.745]}\end{array}$ & $\begin{array}{c}-0.005^{* * *} \\
{[0.001]}\end{array}$ \\
\hline Log age & $\begin{array}{c}0.004 \\
{[0.008]}\end{array}$ & $\begin{array}{c}0.011 \\
{[0.007]}\end{array}$ & $\begin{array}{c}-0.001 \\
{[0.007]}\end{array}$ & $\begin{array}{c}-6.667 * * * \\
{[1.661]}\end{array}$ & $\begin{array}{c}-0.284^{* * *} \\
{[0.020]}\end{array}$ \\
\hline Herfindahl index & $\begin{array}{l}0.326^{*} \\
{[0.194]}\end{array}$ & $\begin{array}{l}0.338^{*} \\
{[0.172]}\end{array}$ & $\begin{array}{l}0.383^{* *} \\
{[0.175]}\end{array}$ & $\begin{array}{l}-78.812 * \\
{[43.496]}\end{array}$ & $\begin{array}{c}0.045 \\
{[0.159]}\end{array}$ \\
\hline Firm and Year FE & $\mathrm{Y}$ & $\mathrm{Y}$ & $\mathrm{Y}$ & $\mathrm{Y}$ & $\mathrm{Y}$ \\
\hline Observations & 248425 & 240278 & 248035 & 583104 & 585692 \\
\hline Number of firms & 77122 & 72025 & 75765 & 144023 & 141335 \\
\hline Adj. R-sq. & 0.563 & 0.566 & 0.564 & 0.780 & 0.176 \\
\hline
\end{tabular}




\section{Table 4: TFP changes Around Interstate Bank Branching Deregulations - By SBA Financing Eligibility of Firm prior to Law Change (Sharp-RD analysis)}

Panel A of this table reports the result for a non-parametric local linear regression discontinuity estimator using optimal bandwidth calculation of Imbens (e.g., Imbens and Lemieux (2008)). Panel B of this table reports results for panel data regressions where the dependent variable is the difference between the average of the (winsorized) TFP of a firm over the three years after the first interstate banking deregulation year of the state of a firm and the average of the TFP over the three years prior to the first interstate banking deregulation year. The independent variables are: SBA ineligible, which is a dummy variable that is one if the firm's employment immediately prior to the firm's state's interstate bank branching deregulation is higher than the SBA employment threshold for the firm's three digit NAICS industry to be classified as a small firm, and zero otherwise; Log normalized employment, which is the log of the firm's employment immediately prior to the firm's state's interstate bank branching deregulation divided by the SBA employment threshold for the firm's three digit NAICS industry; Log normalized employment ${ }^{2}$; Log assets, which is the natural log of the one year lagged value of the firm's capital stock; Log age, which is the natural logarithm of the firm's age; Herfindahl index, which is the one year lagged concentration of the firm's three digit NAICS industry (winsorized at the one percent level); Average prior 3 year TFP, which is the average of the TFP over the three years prior to the year of the first interstate bank branching deregulation in the state of the firm; and 3digit NAICS industry, state, and year fixed effects. Column (1) reports the regression results with the sample of firms whose employment prior to the interstate banking deregulation is within 10 percent of the SBA threshold. Column (2) reports the regression results with the sample of firms whose employment prior to the interstate banking deregulation is within 30 percent of the SBA threshold. Column (3) reports the regression results with the sample of firms whose employment prior to the interstate banking deregulation is within 50 percent of the SBA threshold. Column (4) reports the regression results with the complete sample. Heteroskedasticity corrected robust standard errors, which are clustered on state, are in brackets. All regressions are estimated with an intercept term. ***, **, and * represent statistical significance at the 1,5 , and 10 percent levels, respectively.

\begin{tabular}{|c|c|c|c|c|}
\hline Panel A: Local linear regression estimate & Coeff & SE & & \\
\hline & $0.023^{* * *}$ & 0.010 & & \\
\hline \multicolumn{5}{|l|}{ Panel B: Parametric RD analysis } \\
\hline & $(1)$ & $(2)$ & $(3)$ & $(4)$ \\
\hline & $10 \%$ sample & $30 \%$ sample & $50 \%$ sample & Full sample \\
\hline SBA ineligible & $\begin{array}{l}0.071^{*} \\
{[0.040]}\end{array}$ & $\begin{array}{c}0.056^{* * *} \\
{[0.017]}\end{array}$ & $\begin{array}{c}0.049 * * * \\
{[0.014]}\end{array}$ & $\begin{array}{c}0.036^{* * *} \\
{[0.007]}\end{array}$ \\
\hline Log norm. employment & $\begin{array}{l}-0.486 \\
{[0.325]}\end{array}$ & $\begin{array}{c}-0.153 * * \\
{[0.072]}\end{array}$ & $\begin{array}{c}-0.049 \\
{[0.046]}\end{array}$ & $\begin{array}{c}-0.004 \\
{[0.004]}\end{array}$ \\
\hline Log norm employment ${ }^{2}$ & $\begin{array}{c}-2.482 \\
{[2.830]}\end{array}$ & $\begin{array}{c}-0.445^{* *} \\
{[0.181]}\end{array}$ & $\begin{array}{c}-0.058 \\
{[0.074]}\end{array}$ & $\begin{array}{l}0.002^{* *} \\
{[0.001]}\end{array}$ \\
\hline Log assets & $\begin{array}{c}0.004 \\
{[0.010]}\end{array}$ & $\begin{array}{c}0.006 \\
{[0.008]}\end{array}$ & $\begin{array}{c}0.003 \\
{[0.006]}\end{array}$ & $\begin{array}{c}0.002 \\
{[0.002]}\end{array}$ \\
\hline Log age & $\begin{array}{l}-0.023 \\
{[0.024]}\end{array}$ & $\begin{array}{c}-0.017 \\
{[0.019]}\end{array}$ & $\begin{array}{c}-0.017 \\
{[0.014]}\end{array}$ & $\begin{array}{c}0.001 \\
{[0.007]}\end{array}$ \\
\hline Herfindahl index & $\begin{array}{c}0.743 \\
{[1.852]}\end{array}$ & $\begin{array}{c}-0.761 \\
{[1.287]}\end{array}$ & $\begin{array}{c}-0.160 \\
{[1.142]}\end{array}$ & $\begin{array}{l}-1.172 * \\
{[0.690]}\end{array}$ \\
\hline Average prior 3 year TFP & $\begin{array}{c}-0.171^{* *} \\
{[0.070]}\end{array}$ & $\begin{array}{c}-0.219 * * * \\
{[0.042]}\end{array}$ & $\begin{array}{c}-0.223^{* * *} \\
{[0.031]}\end{array}$ & $\begin{array}{c}-0.259 * * * \\
{[0.027]}\end{array}$ \\
\hline Industry, State, and Year FE & $\mathrm{Y}$ & $\mathrm{Y}$ & $\mathrm{Y}$ & $\mathrm{Y}$ \\
\hline Observations & 553 & 1162 & 2077 & 6596 \\
\hline Adj. R-sq. & 0.028 & 0.0738 & 0.089 & 0.099 \\
\hline
\end{tabular}




\section{Table 5: TFP changes Around Interstate Bank Branching Deregulations - By SBA Financing Eligibility of Firm prior to Law Change (Sharp RD analysis), Additional Robustness Checks}

This table reports results for panel data regressions where the dependent variable is the difference between the average of the (winsorized) TFP of a firm over the three years after the first interstate banking deregulation year of the state of a firm and the average of the TFP over the three years prior to the first interstate banking deregulation year. The independent variables are: SBA ineligible, which is a dummy variable that is one if the firm's employment immediately prior to the firm's state's interstate bank branching deregulation is higher than the SBA employment threshold for the firm's three digit NAICS industry to be classified as a small firm, and zero otherwise; Log normalized employment, which is the log of the firm's employment immediately prior to the firm's state's interstate bank branching deregulation divided by the SBA employment threshold for the firm's three digit NAICS industry; Log normalized employment ${ }^{2}$; Log normalized employment ${ }^{3}$; SBA ineligible dummy interacted with Log normalized employment, Log normalized employment ${ }^{2}$ and Log normalized employment ${ }^{3}$; Log assets, which is the natural $\log$ of the one year lagged value of the firm's capital stock; Log age, which is the natural logarithm of the firm's age; Herfindahl index, which is the one year lagged concentration of the firm's three digit NAICS industry (winsorized at the one percent level); Average prior 3 year TFP, which is the average of the TFP over the three years prior to the year of the first interstate bank branching deregulation in the state of the firm; and 3-digit NAICS industry, state, and year fixed effects. Columns (1) through (5) report the regression results for the full sample with different powers of Log normalized employment and interaction terms between SBA ineligible with different powers of Log normalized employment. Heteroskedasticity corrected robust standard errors, which are clustered on state, are in brackets. All regressions are estimated with an intercept term. ${ }^{* * *},{ }^{* *}$, and ${ }^{*}$ represent statistical significance at the 1,5 , and 10 percent levels, respectively.

\begin{tabular}{|c|c|c|c|c|c|}
\hline & (1) & (2) & (3) & (4) & (5) \\
\hline & Linear & Cubic & $\begin{array}{l}\text { Linear } \\
\text { spline }\end{array}$ & $\begin{array}{c}\text { Quadratic } \\
\text { spline }\end{array}$ & $\begin{array}{l}\text { Cubic } \\
\text { spline }\end{array}$ \\
\hline SBA ineligible & $\begin{array}{c}0.044^{* * *} \\
{[0.008]}\end{array}$ & $\begin{array}{c}0.029 * * * \\
{[0.010]}\end{array}$ & $\begin{array}{c}0.041^{* * *} \\
{[0.008]}\end{array}$ & $\begin{array}{l}0.028^{* *} \\
{[0.011]}\end{array}$ & $\begin{array}{c}0.035^{* * *} \\
{[0.011]}\end{array}$ \\
\hline Log norm. employment & $\begin{array}{c}-0.011 * * * \\
{[0.004]}\end{array}$ & $\begin{array}{c}0.002 \\
{[0.006]}\end{array}$ & $\begin{array}{c}-0.013 * * * \\
{[0.004]}\end{array}$ & $\begin{array}{c}0.013 \\
{[0.011]}\end{array}$ & $\begin{array}{c}0.007 \\
{[0.013]}\end{array}$ \\
\hline Log norm. employment ${ }^{2}$ & & $\begin{array}{c}0.001 \\
{[0.001]}\end{array}$ & & $\begin{array}{l}0.006^{* *} \\
{[0.003]}\end{array}$ & $\begin{array}{c}0.003 \\
{[0.008]}\end{array}$ \\
\hline Log norm. employment ${ }^{3}$ & & $\begin{array}{l}-0.001 \\
{[0.000]}\end{array}$ & & & $\begin{array}{c}-0.000 \\
{[0.001]}\end{array}$ \\
\hline SBA ineligible *Log norm. employment & & & $\begin{array}{c}0.009 \\
{[0.006]}\end{array}$ & $\begin{array}{c}-0.022 \\
{[0.017]}\end{array}$ & $\begin{array}{c}-0.042 \\
{[0.029]}\end{array}$ \\
\hline SBA ineligible $*$ Log norm. employment ${ }^{2}$ & & & & $\begin{array}{l}-0.004 \\
{[0.005]}\end{array}$ & $\begin{array}{c}0.022 \\
{[0.017]}\end{array}$ \\
\hline SBA ineligible ${ }^{*}$ Log norm. employment ${ }^{3}$ & & & & & $\begin{array}{c}-0.004 \\
{[0.003]}\end{array}$ \\
\hline Log assets & $\begin{array}{c}0.003 \\
{[0.002]}\end{array}$ & $\begin{array}{c}0.002 \\
{[0.002]}\end{array}$ & $\begin{array}{c}0.003 \\
{[0.002]}\end{array}$ & $\begin{array}{c}0.002 \\
{[0.002]}\end{array}$ & $\begin{array}{c}0.002 \\
{[0.002]}\end{array}$ \\
\hline Log age & $\begin{array}{l}-0.002 \\
{[0.007]}\end{array}$ & $\begin{array}{c}0.001 \\
{[0.007]}\end{array}$ & $\begin{array}{l}-0.001 \\
{[0.007]}\end{array}$ & $\begin{array}{c}0.001 \\
{[0.007]}\end{array}$ & $\begin{array}{c}0.001 \\
{[0.007]}\end{array}$ \\
\hline Herfindahl index & $\begin{array}{l}-1.149 * \\
{[0.681]}\end{array}$ & $\begin{array}{l}-1.182 * \\
{[0.694]}\end{array}$ & $\begin{array}{l}-1.156^{*} \\
{[0.685]}\end{array}$ & $\begin{array}{l}-1.182 * \\
{[0.693]}\end{array}$ & $\begin{array}{c}-1.187^{*} \\
{[0.690]}\end{array}$ \\
\hline Average prior 3 year TFP & $\begin{array}{c}-0.257 * * * \\
{[0.027]} \\
\end{array}$ & $\begin{array}{c}-0.258 * * * \\
{[0.028]} \\
\end{array}$ & $\begin{array}{c}-0.258^{* * *} * \\
{[0.028]} \\
\end{array}$ & $\begin{array}{c}-0.257 * * * \\
{[0.028]} \\
\end{array}$ & $\begin{array}{c}-0.257 * * * \\
{[0.028]} \\
\end{array}$ \\
\hline Industry, State, and Year FE & $\mathrm{Y}$ & $\mathrm{Y}$ & $\mathrm{Y}$ & $\mathrm{Y}$ & $\mathrm{Y}$ \\
\hline Observations & 6596 & 6596 & 6596 & 6596 & 6596 \\
\hline Adj. R-sq. & 0.098 & 0.100 & 0.099 & 0.100 & 0.100 \\
\hline
\end{tabular}




\section{Table 6: TFP changes Around Interstate Bank Branching Deregulations - By SBA}

Financing Eligibility of Firm prior to Law Change (Sharp RD analysis), Placebo Analysis

This table reports results for panel data regressions where the dependent variable is the difference between the average of the (winsorized) TFP of a firm over the three years after the first interstate banking deregulation year of the state of a firm and the average of the TFP over the three years prior to the first interstate banking deregulation year. The independent variables are: SBA ineligible, which is a dummy variable that is one if the firm's Normalized employment immediately prior to the firm's state's interstate bank branching deregulation is higher than the falsified value of the SBA threshold, and zero otherwise; Log normalized employment, which is the log of the firm's employment immediately prior to the firm's state's interstate bank branching deregulation divided by the SBA employment threshold for the firm's three digit NAICS industry; Log normalized employment ${ }^{2}$; Log assets, which is the natural log of the one year lagged value of the firm's capital stock; Log age, which is the natural logarithm of the firm's age; Herfindahl index, which is the one year lagged concentration of the firm's three digit NAICS industry (winsorized at the one percent level); Average prior 3 year TFP, which is the average of the TFP over the three years prior to the year of the first interstate bank branching deregulation in the state of the firm; and 3-digit NAICS industry, state, and year fixed effects Column (1) reports the regression results by falsifying the SBA eligibility threshold for Normalized employment to 0.8 (actual threshold is 1). Column (2) reports the regression results by falsifying the SBA eligibility threshold for Normalized employment to 1.2. All regressions use the sample of firms whose Normalized employment prior to the interstate banking deregulation is within 10 percentage points of the falsified SBA threshold. Heteroskedasticity corrected robust standard errors, which are clustered on state, are in brackets. All regressions are estimated with an intercept term. $* * *, * *$, and $*$ represent statistical significance at the 1,5 , and 10 percent levels, respectively.

\begin{tabular}{lcc}
\hline & $(1)$ & $(2)$ \\
\hline \multicolumn{1}{c}{ Move discontinuity point by: } & $-20 \%$ & $+20 \%$ \\
\hline SBA ineligible & 0.021 & 0.015 \\
& {$[0.031]$} & {$[0.104]$} \\
Log norm. employment & -0.445 & 1.042 \\
& {$[0.737]$} & {$[3.054]$} \\
Log norm. employment ${ }^{2}$ & -0.802 & -4.663 \\
& {$[1.389]$} & {$[7.629]$} \\
Log assets & 0.012 & 0.013 \\
& {$[0.013]$} & {$[0.019]$} \\
Log age & 0.004 & -0.052 \\
& {$[0.031]$} & {$[0.057]$} \\
Herfindahl index & 2.009 & -3.918 \\
& {$[2.322]$} & {$[2.470]$} \\
Average prior 3 year TFP & $-0.291^{* * *}$ & $-0.235^{* *}$ \\
& {$[0.052]$} & {$[0.095]$} \\
& & \\
\hline Industry, State, and Year FE & $\mathrm{Y}$ & $\mathrm{Y}$ \\
\hline Observations & 454 & 158 \\
Adj. R-sq. & 0.173 & 0.068 \\
\hline
\end{tabular}




\section{Table 7: TFP changes Around Interstate Bank Branching Deregulations - By SBA Financing Eligibility of Firm prior to Law Change (Quasi RD analysis)}

This table reports results for panel data regressions where the dependent variable is the TFP of a firm for a given year (winsorized at the one percent level). The independent variables are: Deregulation index interacted with SBA ineligible, where the Deregulation Index is an index that is one for the state that has the most restrictive interstate bank branching regulations as of the effective date of the state's setting of interstate bank branching restrictions, and increases by one for each restriction that is relaxed by a state (this index takes the value zero in all years prior to the effective date), and SBA ineligible is a dummy variable that is one if the firm's employment immediately prior to the firm's state's interstate bank branching deregulation is higher than the SBA employment threshold for the firm's three digit NAICS industry to be classified as a small firm, and zero otherwise; Deregulation index interacted with SBA eligible, where SBA eligible is a dummy variable that equals one minus SBA ineligible; Deregulation index interacted with Log normalized employment, which is the log of the firm's employment immediately prior to the firm's state's interstate bank branching deregulation divided by the SBA employment threshold for the firm's three digit NAICS industry; Log employment, which is the one year lagged value of the firm's employment; Log employment ${ }^{2}$; Log assets, which is the natural log of the one year lagged value of the firm's capital stock; Log age, which is the natural logarithm of the firm's age; Herfindahl index, which is the one year lagged concentration of the firm's three digit NAICS industry (winsorized at the one percent level); and firm and year fixed effects. Column (1) reports the regression results with the sample of firms whose employment prior to the interstate banking deregulation is within 10 percent of the SBA threshold. Column (2) reports the regression results with the sample of firms whose employment prior to the interstate banking deregulation is within 10 percent of the SBA threshold, and Deregulation index is modified by adding one for states that do not impose a reciprocity requirement in their interstate banking regulations. Column (3) reports the regression results with the sample of firms whose employment prior to the interstate banking deregulation is within 30 percent of the SBA threshold. Column (4) reports the regression results with the sample of firms whose employment prior to the interstate banking deregulation is within 50 percent of the SBA threshold. Column (5) reports the regression results with the complete sample. Heteroskedasticity corrected robust standard errors, which are clustered on state, are in brackets. All regressions are estimated with an intercept term. ${ }^{* * *}, * *$, and $*$ represent statistical significance at the 1,5 , and 10 percent levels, respectively. 


\begin{tabular}{|c|c|c|c|c|c|}
\hline & $(1)$ & (2) & (3) & (4) & (5) \\
\hline & $10 \%$ sample & $\begin{array}{c}10 \% \text { sample - } \\
\text { Deregulation \& } \\
\text { reciprocity index }\end{array}$ & $30 \%$ sample & $50 \%$ sample & Full sample \\
\hline Deregulation index*SBA ineligible & $\begin{array}{l}0.010^{*} \\
{[0.006]}\end{array}$ & $\begin{array}{l}0.012 * * \\
{[0.005]}\end{array}$ & $\begin{array}{l}0.007^{*} \\
{[0.003]}\end{array}$ & $\begin{array}{l}0.005^{* *} \\
{[0.002]}\end{array}$ & $\begin{array}{c}0.006^{* * *} \\
{[0.002]}\end{array}$ \\
\hline Deregulation index *SBA eligible & $\begin{array}{l}-0.011 \\
{[0.009]}\end{array}$ & $\begin{array}{l}-0.009 \\
{[0.007]}\end{array}$ & $\begin{array}{c}0.001 \\
{[0.004]}\end{array}$ & $\begin{array}{c}-0.003 \\
{[0.003]}\end{array}$ & $\begin{array}{l}-0.001 \\
{[0.002]}\end{array}$ \\
\hline Deregulation index *Log norm. employment & $\begin{array}{c}-0.240 * * * \\
{[0.082]}\end{array}$ & $\begin{array}{c}-0.223^{* * *} \\
{[0.075]}\end{array}$ & $\begin{array}{c}-0.002 \\
{[0.013]}\end{array}$ & $\begin{array}{l}-0.010^{*} \\
{[0.006]}\end{array}$ & $\begin{array}{c}-0.002 * * * \\
{[0.000]}\end{array}$ \\
\hline Log employment & $\begin{array}{c}-0.148 * * * \\
{[0.044]}\end{array}$ & $\begin{array}{c}-0.146 * * * \\
{[0.044]}\end{array}$ & $\begin{array}{c}-0.074 \\
{[0.046]}\end{array}$ & $\begin{array}{c}-0.070^{* * * *} \\
{[0.023]}\end{array}$ & $\begin{array}{c}-0.051^{* * *} \\
{[0.007]}\end{array}$ \\
\hline Log employment ${ }^{2}$ & $\begin{array}{c}0.014 * * * \\
{[0.004]}\end{array}$ & $\begin{array}{c}0.014 * * * \\
{[0.004]}\end{array}$ & $\begin{array}{l}0.008^{*} \\
{[0.004]}\end{array}$ & $\begin{array}{c}0.008^{* * *} \\
{[0.002]}\end{array}$ & $\begin{array}{c}0.007^{* * *} \\
{[0.001]}\end{array}$ \\
\hline Log assets & $\begin{array}{l}0.024^{* *} \\
{[0.012]}\end{array}$ & $\begin{array}{l}0.024^{* *} \\
{[0.012]}\end{array}$ & $\begin{array}{c}-0.001 \\
{[0.009]}\end{array}$ & $\begin{array}{c}-0.010^{* *} \\
{[0.005]}\end{array}$ & $\begin{array}{c}-0.029 * * * \\
{[0.002]}\end{array}$ \\
\hline Log age & $\begin{array}{l}-0.012 \\
{[0.027]}\end{array}$ & $\begin{array}{c}-0.012 \\
{[0.027]}\end{array}$ & $\begin{array}{l}-0.008 \\
{[0.019]}\end{array}$ & $\begin{array}{c}0.012 \\
{[0.013]}\end{array}$ & $\begin{array}{c}0.003 \\
{[0.007]}\end{array}$ \\
\hline Herfindahl index & $\begin{array}{l}-0.127 \\
{[0.451]}\end{array}$ & $\begin{array}{l}-0.131 \\
{[0.448]}\end{array}$ & $\begin{array}{c}0.038 \\
{[0.295]}\end{array}$ & $\begin{array}{c}0.246 \\
{[0.234]}\end{array}$ & $\begin{array}{c}0.360^{* * *} \\
{[0.108]}\end{array}$ \\
\hline Firm and Year FE & $\mathrm{Y}$ & $\mathrm{Y}$ & $\mathrm{Y}$ & $\mathrm{Y}$ & $\mathrm{Y}$ \\
\hline Observations & 11146 & 11146 & 23957 & 43472 & 220625 \\
\hline Number of firms & 817 & 817 & 1754 & 3274 & 30702 \\
\hline Adj. R-sq. & 0.515 & 0.515 & 0.512 & 0.517 & 0.486 \\
\hline $\begin{array}{l}\text { After* SBA ineligible - } \\
\text { After* SBA eligible }\end{array}$ & $0.021^{* *}$ & $0.021^{* *}$ & 0.006 & $0.008 *$ & $0.007^{* * *}$ \\
\hline
\end{tabular}




\section{Table 8: TFP changes Around Interstate Bank Branching Deregulations - By SBA Financing Eligibility of Firm prior to Law Change (Quasi RD analysis), Additional Robustness Checks}

This table reports results for panel data regressions the dependent variable is the TFP of a firm for a given year (winsorized at the one percent level). The independent variables are: Deregulation index interacted with SBA ineligible, where the Deregulation Index is an index that is one for the state that has the most restrictive interstate bank branching regulations as of the effective date of the state's setting of interstate bank branching restrictions, and increases by one for each restriction that is relaxed by a state (this index takes the value zero in all years prior to the effective date), and SBA ineligible is a dummy variable that is one if the firm's employment immediately prior to the firm's state's interstate bank branching deregulation is higher than the SBA employment threshold for the firm's three digit NAICS industry to be classified as a small firm, and zero otherwise; Deregulation index interacted with $S B A$ eligible, where SBA eligible is a dummy variable that equals one minus SBA ineligible; Deregulation index interacted with Log normalized employment, which is the log of the firm's employment immediately prior to the firm's state's interstate bank branching deregulation divided by the SBA employment threshold for the firm's three digit NAICS industry; Deregulation index interacted with Log normalized employment ${ }^{2}$; Deregulation index interacted with Log normalized employment ${ }^{3}$; Log employment, which is the one year lagged value of the firm's employment; Log employment ${ }^{2}$; Log assets, which is the natural log of the one year lagged value of the firm's capital stock; Log age, which is the natural logarithm of the firm's age; Herfindahl index, which is the one year lagged concentration of the firm's three digit NAICS industry (winsorized at the one percent level); and firm and year fixed effects. All models report regression results with the complete sample. Columns (1) through (4) report the regression results for the full sample with different powers of Log employment and interaction terms between Deregulation Index with different powers of Log normalized employment. Heteroskedasticity corrected robust standard errors, which are clustered on state, are in brackets. All regressions are estimated with an intercept term. $* * *, * *$, and $*$ represent statistical significance at the 1,5 , and 10 percent levels, respectively. 


\begin{tabular}{|c|c|c|c|c|}
\hline & $(1)$ & $(2)$ & (3) & $(4)$ \\
\hline & Linear & Cubic & $\begin{array}{l}\text { Quadratic } \\
\text { interaction }\end{array}$ & $\begin{array}{c}\text { Cubic } \\
\text { interaction }\end{array}$ \\
\hline Deregulation index*SBA ineligible & $\begin{array}{c}0.008^{* * *} \\
{[0.001]}\end{array}$ & $\begin{array}{c}0.006^{* * *} \\
{[0.002]}\end{array}$ & $\begin{array}{c}0.005^{* * *} \\
{[0.002]}\end{array}$ & $\begin{array}{c}0.005^{* * *} \\
{[0.002]}\end{array}$ \\
\hline Deregulation index *SBA eligible & $\begin{array}{c}-0.000 \\
{[0.002]}\end{array}$ & $\begin{array}{c}-0.001 \\
{[0.002]}\end{array}$ & $\begin{array}{l}-0.000 \\
{[0.002]}\end{array}$ & $\begin{array}{c}0.000 \\
{[0.002]}\end{array}$ \\
\hline Deregulation index *Log norm. employment & $\begin{array}{c}-0.002 * * * \\
{[0.000]}\end{array}$ & $\begin{array}{c}-0.002 * * * \\
{[0.000]}\end{array}$ & $\begin{array}{c}-0.000 \\
{[0.001]}\end{array}$ & $\begin{array}{l}-0.000 \\
{[0.001]}\end{array}$ \\
\hline Deregulation index $*$ Log norm. employment ${ }^{2}$ & & & $\begin{array}{l}0.000^{*} \\
{[0.000]}\end{array}$ & $\begin{array}{c}0.000 \\
{[0.000]}\end{array}$ \\
\hline Deregulation index *Log norm. employment ${ }^{3}$ & & & & $\begin{array}{c}-0.000 \\
{[0.000]}\end{array}$ \\
\hline Log employment & $\begin{array}{c}0.008^{* * *} \\
{[0.003]}\end{array}$ & $\begin{array}{c}-0.023 \\
{[0.023]}\end{array}$ & $\begin{array}{c}-0.050^{* * *} \\
{[0.008]}\end{array}$ & $\begin{array}{c}-0.024 \\
{[0.023]}\end{array}$ \\
\hline Log employment $^{2}$ & & $\begin{array}{c}0.000 \\
{[0.005]}\end{array}$ & $\begin{array}{c}0.007^{* * *} \\
{[0.001]}\end{array}$ & $\begin{array}{c}0.000 \\
{[0.005]}\end{array}$ \\
\hline Log employment ${ }^{3}$ & & $\begin{array}{c}0.000 \\
{[0.000]}\end{array}$ & & $\begin{array}{c}0.000 \\
{[0.000]}\end{array}$ \\
\hline Log assets & $\begin{array}{c}-0.026 * * * \\
{[0.002]}\end{array}$ & $\begin{array}{c}-0.029 * * * \\
{[0.002]}\end{array}$ & $\begin{array}{c}-0.029 * * * \\
{[0.002]}\end{array}$ & $\begin{array}{c}-0.029 * * * \\
{[0.002]}\end{array}$ \\
\hline Log age & $\begin{array}{l}-0.002 \\
{[0.007]}\end{array}$ & $\begin{array}{c}0.003 \\
{[0.007]}\end{array}$ & $\begin{array}{c}0.003 \\
{[0.007]}\end{array}$ & $\begin{array}{c}0.003 \\
{[0.007]}\end{array}$ \\
\hline Herfindahl index & $\begin{array}{c}0.349 * * * \\
{[0.111]}\end{array}$ & $\begin{array}{c}0.359 * * * \\
{[0.108]}\end{array}$ & $\begin{array}{c}0.359 * * * \\
{[0.109]}\end{array}$ & $\begin{array}{c}0.357^{* * *} \\
{[0.108]}\end{array}$ \\
\hline Firm and Year FE & $\mathrm{Y}$ & $\mathrm{Y}$ & $\mathrm{Y}$ & $\mathrm{Y}$ \\
\hline Observations & 220625 & 220625 & 220625 & 220625 \\
\hline Number of firms & 30702 & 30702 & 30702 & 30702 \\
\hline Adj. R-sq. & 0.485 & 0.486 & 0.486 & 0.486 \\
\hline $\begin{array}{l}\text { After* SBA ineligible - } \\
\text { After* SBA eligible }\end{array}$ & $0.008 * * *$ & $0.007 * * *$ & $0.005^{* *}$ & $0.005^{* *}$ \\
\hline
\end{tabular}




\section{Table 9: TFP changes Around Interstate Bank Branching Deregulations - By SBA}

Financing Eligibility of Firm prior to Law Change (Quasi RD analysis), Placebo Analysis

This table reports results for panel data regressions where the dependent variable is the TFP of a firm for a given year (winsorized at the one percent level). The independent variables are: Deregulation index interacted with SBA ineligible, where the Deregulation Index is an index that is one for the state that has the most restrictive interstate bank branching regulations as of the effective date of the state's setting of interstate bank branching restrictions, and increases by one for each restriction that is relaxed by a state (this index takes the value zero in all years prior to the effective date), and SBA ineligible, which is a dummy variable that is one if the firm's Normalized employment immediately prior to the firm's state's interstate bank branching deregulation is higher than the falsified value of the SBA threshold, and zero otherwise; Deregulation index interacted with SBA eligible, where SBA eligible is a dummy variable that equals one minus SBA ineligible; Deregulation index interacted with Log normalized employment, which is the log of the firm's employment immediately prior to the firm's state's interstate bank branching deregulation divided by the SBA employment threshold for the firm's three digit NAICS industry; Deregulation index interacted with Log normalized employment ${ }^{2}$; Deregulation index interacted with Log normalized employment $t^{3}$ Log employment, which is the one year lagged value of the firm's employment; Log employment ${ }^{2}$ Log assets, which is the natural log of the one year lagged value of the firm's capital stock; Log age, which is the natural logarithm of the firm's age; Herfindahl index, which is the one year lagged concentration of the firm's three digit NAICS industry (winsorized at the one percent level); and firm and year fixed effects. Column (1) reports the regression results by falsifying the SBA eligibility threshold for Normalized employment to 0.8 (actual threshold is 1). Column (2) reports the regression results by falsifying the SBA eligibility threshold for Normalized employment to 1.2. All regressions use the sample of firms whose Normalized employment prior to the interstate banking deregulation is within 10 percentage points of the falsified SBA threshold. Heteroskedasticity corrected robust standard errors, which are clustered on state, are in brackets. All regressions are estimated with an intercept term. $* * *, * *$, and * represent statistical significance at the 1,5 , and 10 percent levels, respectively.

\begin{tabular}{lcc}
\hline & $(1)$ & $(2)$ \\
\hline \multicolumn{1}{c}{ Move discontinuity point by: } & $-20 \%$ & $+20 \%$ \\
\hline Deregulation index*SBA ineligible & 0.002 & -0.001 \\
& {$[0.035]$} & {$[0.022]$} \\
Deregulation index *SBA eligible & 0.001 & -0.023 \\
& {$[0.021]$} & {$[0.030]$} \\
Deregulation index *Log norm. employment & -0.022 & 0.100 \\
& {$[0.107]$} & {$[0.119]$} \\
Log employment & -0.025 & 0.051 \\
& {$[0.069]$} & {$[0.105]$} \\
Log employment ${ }^{2}$ & 0.006 & -0.005 \\
& {$[0.006]$} & {$[0.008]$} \\
Log assets & $-0.034 * * *$ & 0.014 \\
& {$[0.011]$} & {$[0.020]$} \\
Log age & -0.023 & 0.084 \\
& {$[0.035]$} & {$[0.103]$} \\
Herfindahl index & -0.179 & 0.863 \\
& {$[0.391]$} & {$[0.568]$} \\
\hline Firm and Year FE & $\mathrm{Y}$ & $\mathrm{Y}$ \\
\hline Observations & 9785 & 3026 \\
Number of firms & 720 & 242 \\
Adj. R-sq. & 0.517 & 0.484 \\
After* SBA ineligible - & & \\
After* SBA eligible & -0.001 & -0.022 \\
\hline
\end{tabular}




\section{Table 10: TFP changes Around Interstate Bank Branching Deregulations - By Firm Size Quintiles}

This table reports results for panel data regressions where the dependent variable is the TFP of a firm for a given year (winsorized at the one percent level). The independent variables in Panel A are: an interaction term between Deregulation Index, which is an index that is one for the state that has the most restrictive interstate bank branching regulations as of the effective date of the state's setting of interstate bank branching restrictions, and increases by one for each restriction that is relaxed by a state (this index takes the value zero in all years prior to the effective date), and each of the five size quintiles (i.e., Size Quintile 1, and so on). Columns (1) and (2) use size quintile bins based on sales, whereas Columns (3) and (4) use size quintile bins based on assets. Columns (2) and (4) in Panel A use the Deregulation index that is modified by adding one for states that do not impose a reciprocity requirement in their interstate banking regulations. The independent variables in Panel B are: interactions term between interaction terms between Deregulation index and each of the five employment bins (i.e., for employment between 1 and 10, between 11 and 20, between 21 and 50, between 51 and 100, and greater than 100). Column (2) in Panel B uses the Deregulation index that is modified by adding one for states that do not impose a reciprocity requirement in their interstate banking regulations. Other independent variables common to both Panels (A) and (B) are: Log assets, which is the natural log of the one year lagged value of the firm's capital stock; Log assets ${ }^{2}$; Log age, which is the natural logarithm of firm age; Herfindahl index, which is the one year lagged concentration of the firm's three digit NAICS industry (winsorized at the one percent level); and firm and year fixed effects. Heteroskedasticity corrected robust standard errors, which are clustered on state, are in brackets. All regressions are estimated with an intercept term. ${ }^{* * *},{ }^{* *}$, and $*$ represent statistical significance at the 1,5 , and 10 percent levels, respectively.

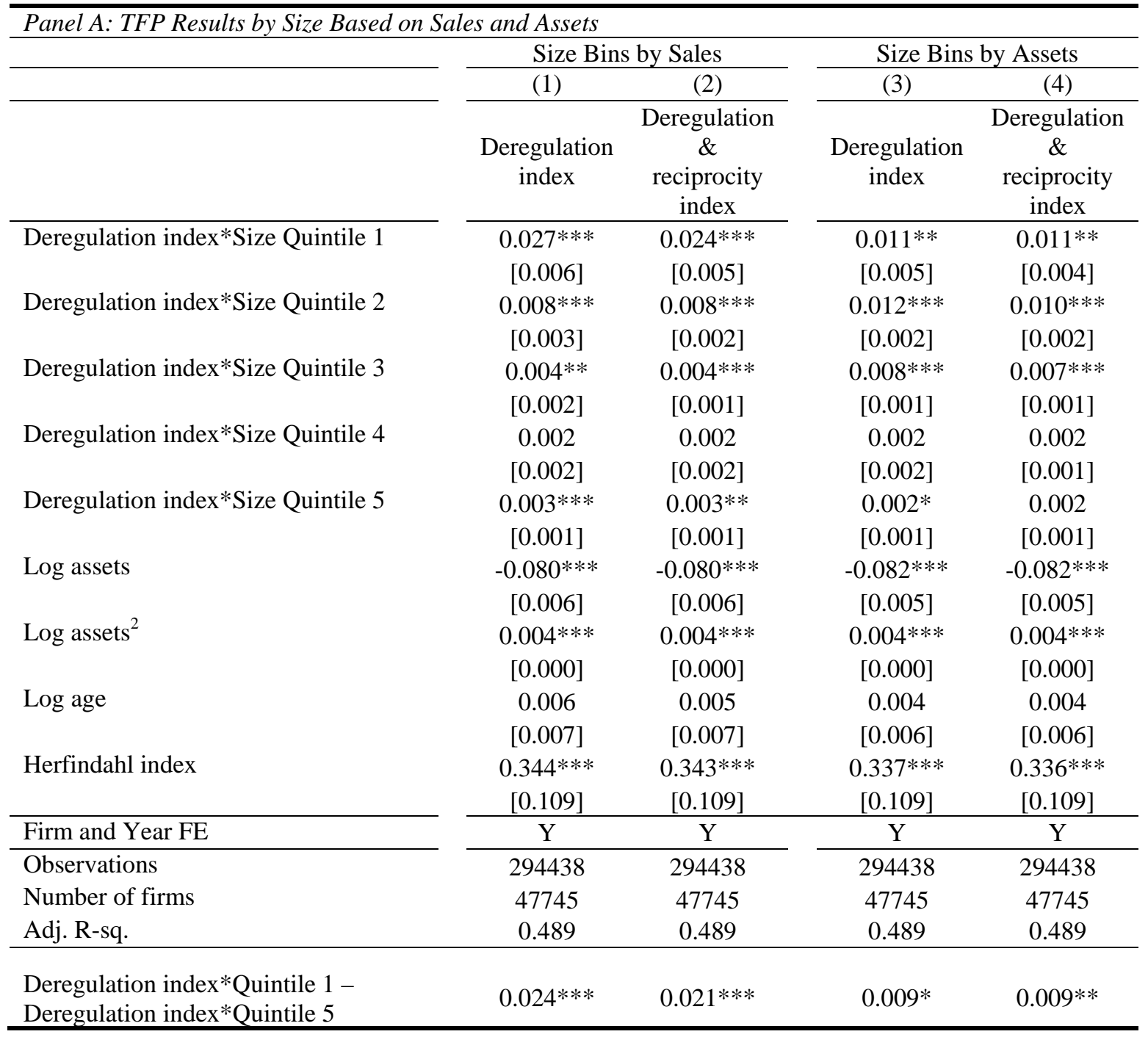




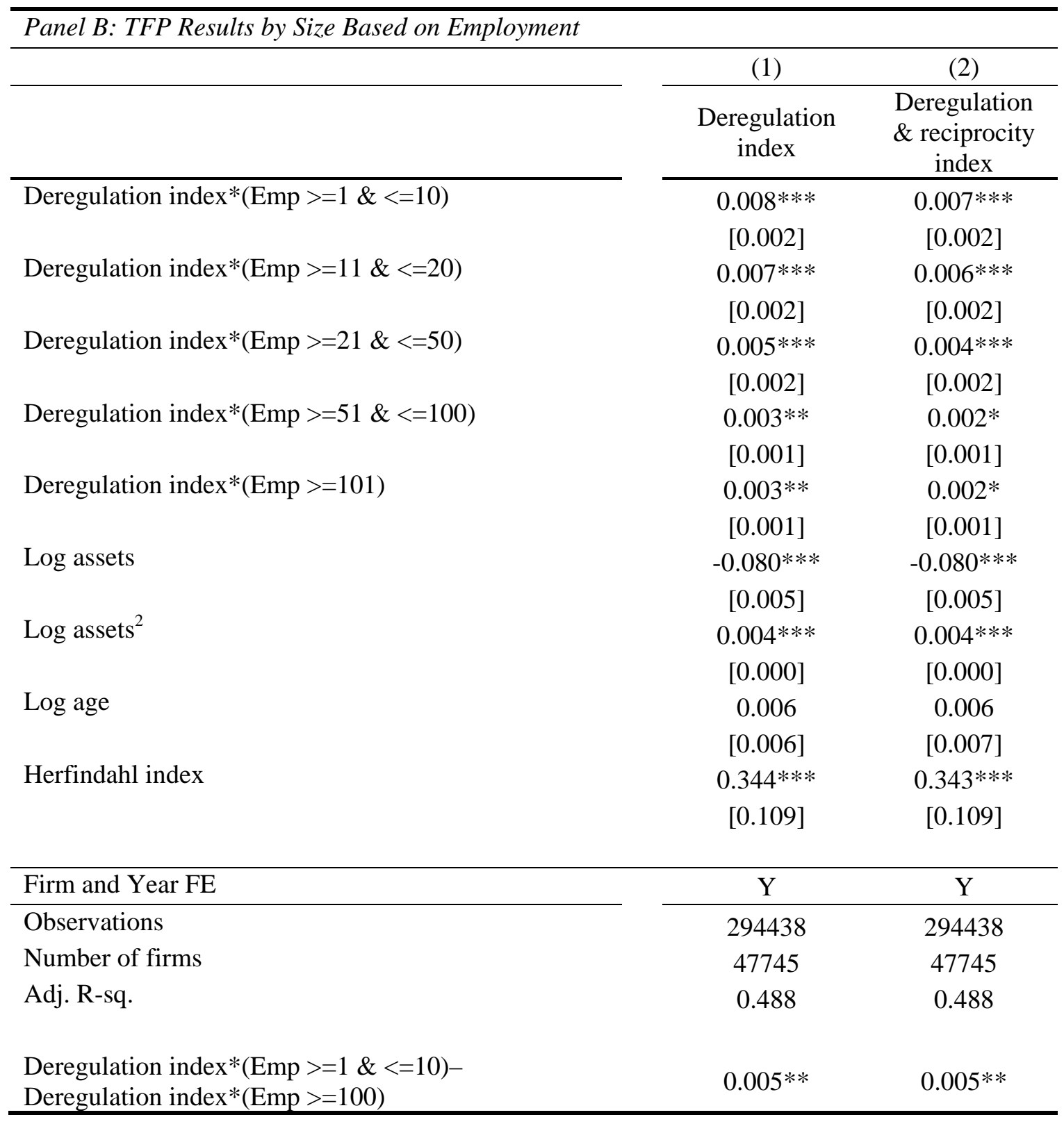




\section{Table 11: TFP changes Around Interstate Bank Branching Deregulations - By External Financing Dependence of the Firm's Industry}

This table reports results for panel data regressions where the dependent variable is the TFP of a firm for a given year industry (winsorized at the one percent level). The independent variables are: an interaction term between Deregulation Index, which is an index that is one for the state that has the most restrictive interstate bank branching regulations as of the effective date of the state's setting of interstate bank branching restrictions, and increases by one for each restriction that is relaxed by a state (this index takes the value zero in all years prior to the effective date), and High External Financial Dependence, which is a dummy variable that is one if the firm is in a three digit NAICS industry that is classified as highly dependent on external finance based on Rajan and Zingales' (1998) measure, and zero otherwise; an interaction term between Deregulation index and Low External Financial Dependence, which is one minus the High External Financial dummy; Log assets, which is the natural log of the one year lagged value of the firm's capital stock; $\log$ assets $^{2}$; Log age, which is the natural logarithm of the firm's age; Herfindahl index, which is the one year lagged concentration of the firm's three digit NAICS industry industry (winsorized at the one percent level); and firm and year fixed effects. Heteroskedasticity corrected robust standard errors, which are clustered on state, are in brackets. All regressions are estimated with an intercept term. ***, **, and * represent statistical significance at the 1,5 , and 10 percent levels, respectively.

\begin{tabular}{|c|c|c|}
\hline & (1) & (2) \\
\hline & $\begin{array}{l}\text { Deregulation } \\
\quad \text { index }\end{array}$ & $\begin{array}{c}\text { Deregulation \& } \\
\text { reciprocity } \\
\text { index }\end{array}$ \\
\hline Deregulation index*High External Financial Dependence & $\begin{array}{c}0.008 * * * \\
{[0.003]}\end{array}$ & $\begin{array}{c}0.008 * * * \\
{[0.002]}\end{array}$ \\
\hline Deregulation index*Low External financial Dependence & $\begin{array}{c}0.003^{* * *} \\
{[0.001]}\end{array}$ & $\begin{array}{c}0.003 * * * \\
{[0.001]}\end{array}$ \\
\hline Log assets & $\begin{array}{c}-0.068 * * * \\
{[0.006]}\end{array}$ & $\begin{array}{c}-0.068 * * * \\
{[0.006]}\end{array}$ \\
\hline 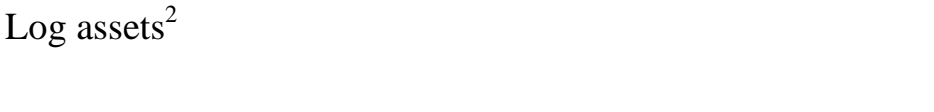 & $\begin{array}{c}0.003^{* * * *} \\
{[0.000]}\end{array}$ & $\begin{array}{c}0.003^{* * *} \\
{[0.000]}\end{array}$ \\
\hline Log age & $\begin{array}{l}-0.006 \\
{[0.005]}\end{array}$ & $\begin{array}{l}-0.006 \\
{[0.005]}\end{array}$ \\
\hline Herfindahl index & $\begin{array}{l}0.276 * * \\
{[0.106]}\end{array}$ & $\begin{array}{c}0.274^{* *} \\
{[0.106]}\end{array}$ \\
\hline Firm and Year FE & $\mathrm{Y}$ & $\mathrm{Y}$ \\
\hline Observations & 570550 & 570550 \\
\hline $\begin{array}{l}\text { Number of firms } \\
\text { Adj. R-sq. }\end{array}$ & $\begin{array}{c}137006 \\
0.517\end{array}$ & $\begin{array}{c}137006 \\
0.517\end{array}$ \\
\hline $\begin{array}{l}\text { Deregulation index*High External Financial Dependence - } \\
\text { Deregulation index*Low External Financial Dependence }\end{array}$ & $0.005^{* *}$ & $0.005^{* *}$ \\
\hline
\end{tabular}


Figure 1: Number of bank establishments in years ending with 2 or 7 (economic census years),

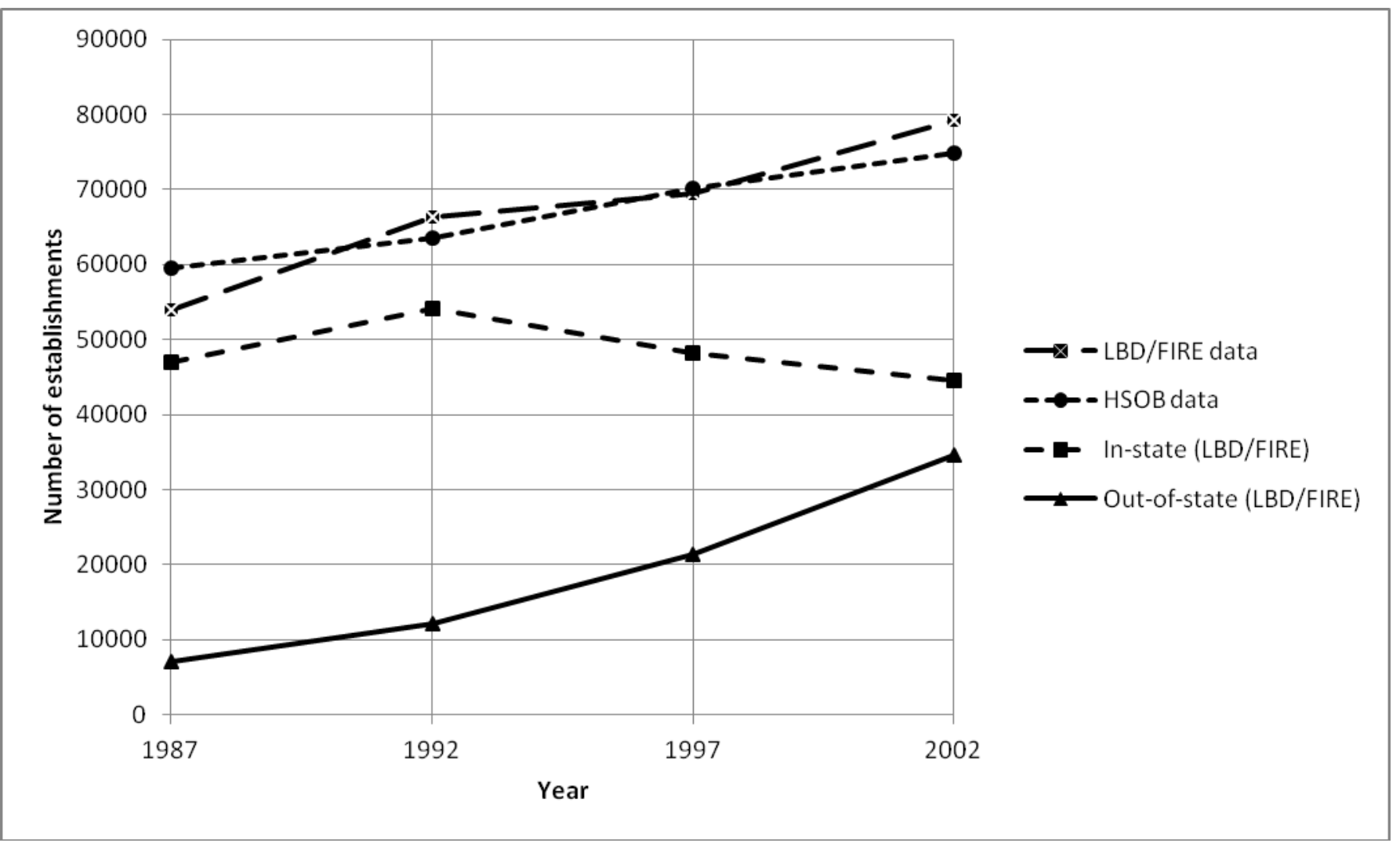


Figure 2: Change in 3 year average TFP from before to after the interstate bank branching deregulation around the SBA eligibility threshold.

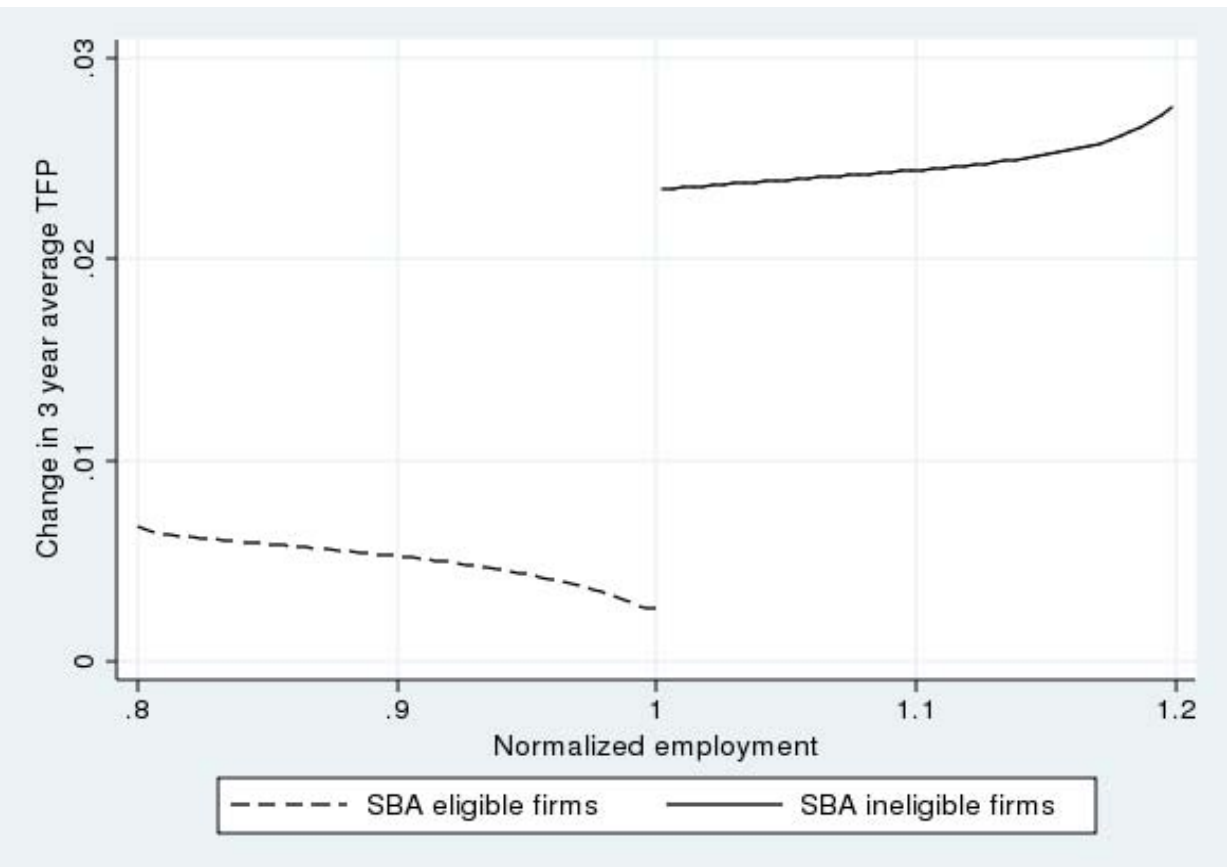

Figure 3: Change in yearly TFP from before to after the interstate bank branching deregulation around the SBA eligibility threshold.

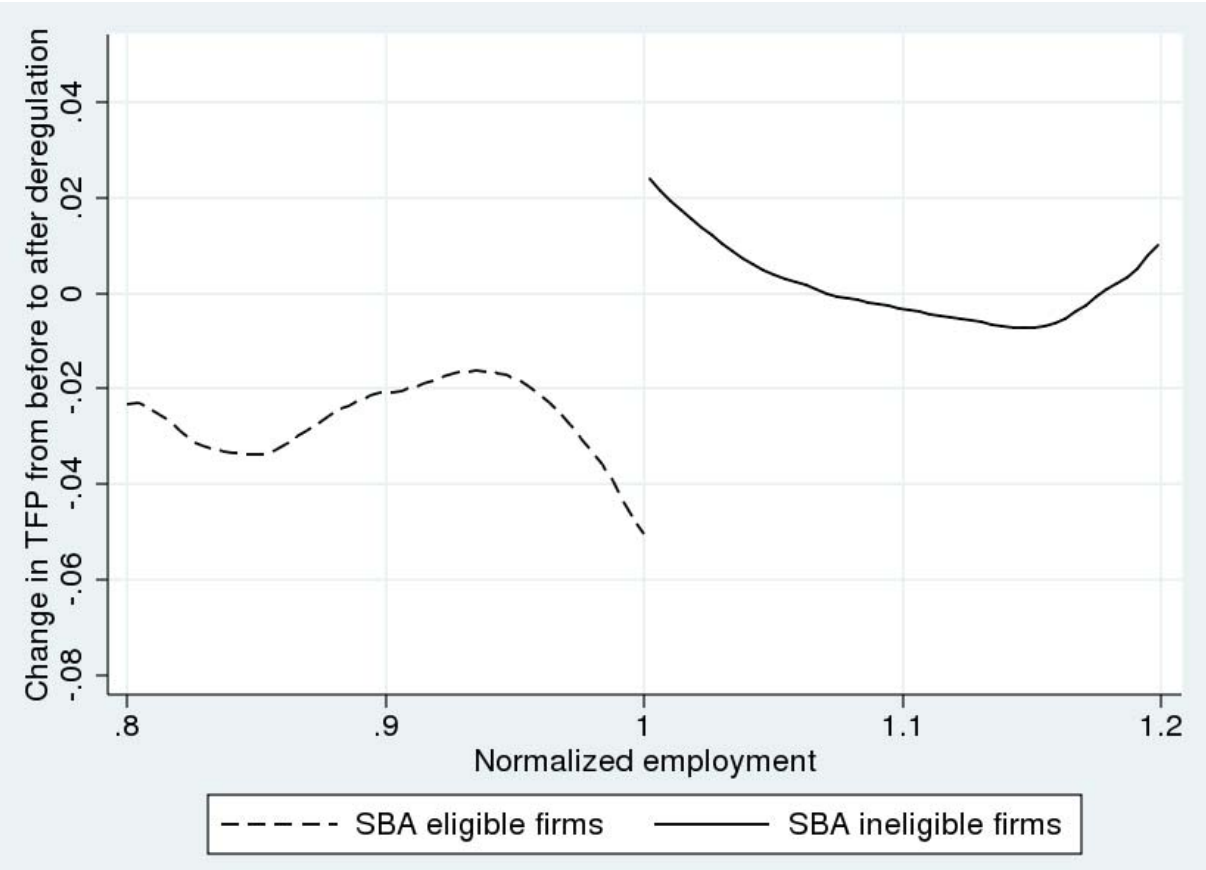


Figure 4: Density of Normalized Employment
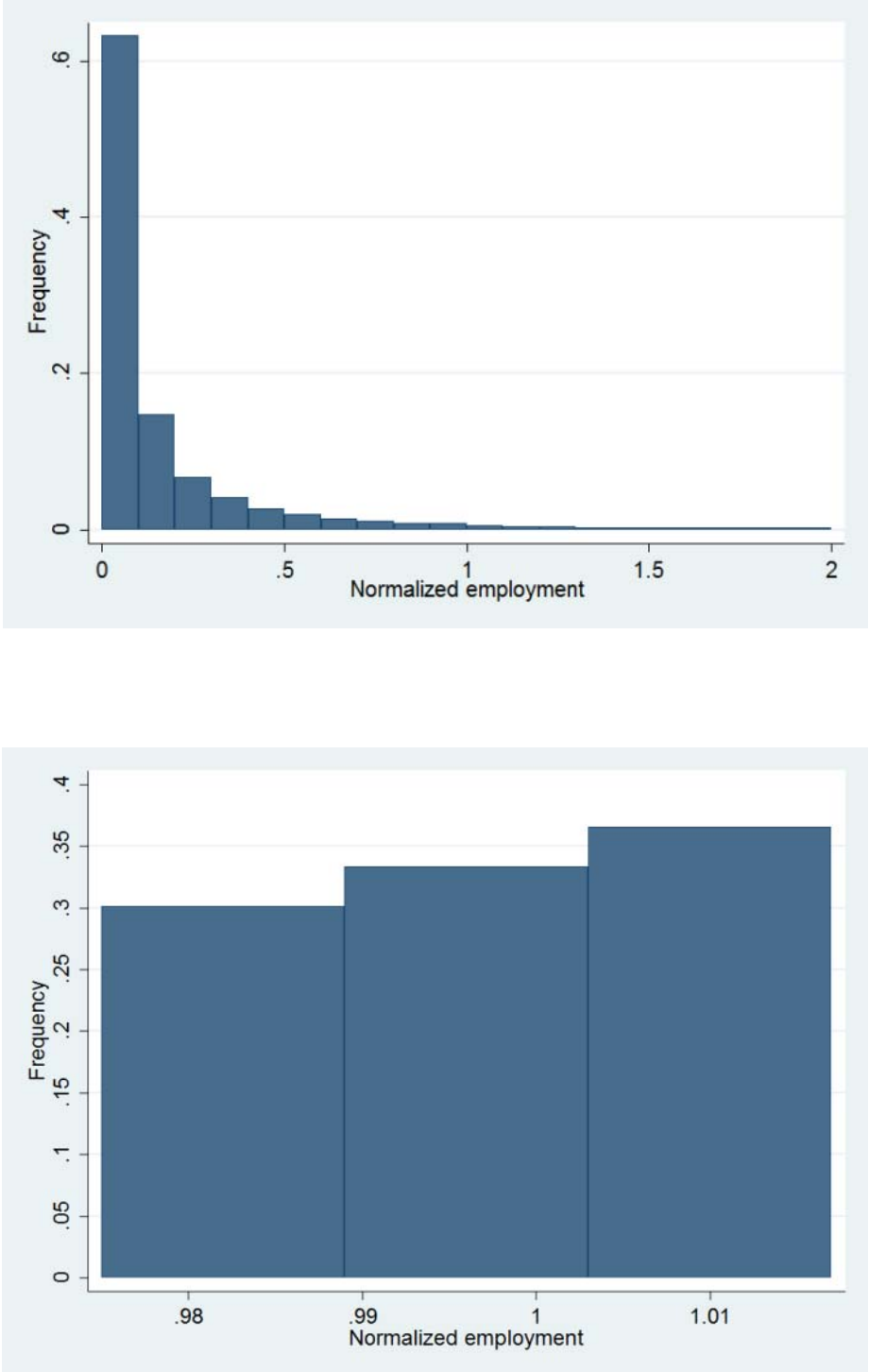